
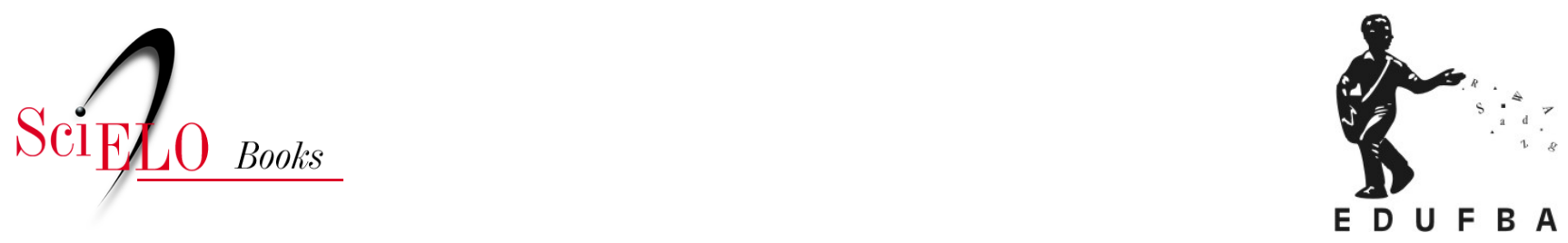

\title{
Qualificação da informação \\ aperfeiçoamento na operacionalização do Cadastro para validação de uma base de dados sobre a população pobre
}

José Carlos da Exaltação Torres

\section{SciELO Books / SciELO Livros / SciELO Libros}

TORRES, J.C.E. Qualificação da informação: aperfeiçoamento na operacionalização do Cadastro para validação de uma base de dados sobre a população pobre. In: Cadastro Único: tecnologia de reclassificação social [online]. Salvador: EDUFBA, 2016, pp. 183-226. ISBN: 978-65-5630-011-5. https://doi.org/10.7476/9786556300115.0011. \section{International license.}

All the contents of this work, except where otherwise noted, is licensed under a Creative Commons Attribution 4.0

Todo o conteúdo deste trabalho, exceto quando houver ressalva, é publicado sob a licença Creative Commons Atribição 4.0. 


\section{QUALIFICAÇÃO DA INFORMAÇÃO: APERFEIÇOAMENTO NA OPERACIONALIZAÇÃO DO CADASTRO PARA VALIDAÇÃO DE UMA BASE DE DADOS SOBRE A POPULAÇÃO POBRE}

Este capítulo analisa as várias medidas práticas adotadas pelo governo federal, através do MDS, a partir de 2005, em relação ao Cadastro Único, e que modificam significativamente o seu processo de operacionalização, uma vez que estabelecem regras e procedimentos mais rígidos para o levantamento, registro e uso dos dados e informações nele contidos. Esta análise demonstra a existência de uma estrutura tecnológica e institucional que ampara a implantação e o gerenciamento das políticas sociais no Brasil atual, através da qual se define "quem são os pobres" do país. A partir de 2005, estabeleceu-se uma linha sistemática de ações cujo cerne está no aprimoramento da gestão do Cadastro, tendo como ponto de partida a verificação de consistência dos dados registrados. Essa iniciativa responde a todo um conjunto de críticas e denúncias das quais o Cadastro Único foi alvo desde a sua implantação, críticas das quais, como se viu, o próprio governo foi signatário quando eleito, no período de transição e em seu primeiro ano de gestão, mas que se tornaram incontornáveis após a criação do PBF, culminando num amplo debate quanto ao futuro do Cadastro; quanto à sua manutenção ou substituição. Por outro lado, pode-se observar que as medidas adotadas atendem à maioria das recomendações feitas pelo TCU após a realização de auditoria sobre o Cadastro Único em 2002, no intuito de qualificar o Cadastro, "por meio do aperfeiçoamento do processo de cadastramento e da verificação da consistência dos dados". (BRASIL, 2003m, p. 3) As normas, orientações e 
informes produzidos entre os anos de 2005 e 2006 reconstituem a trajetória do CadÚnico rumo à sua qualificação.

\section{MUDANÇAS NA TECNOLOGIA E NO MODELO DE GESTÃO DAS INFORMAÇÕES DO CADASTRO ÚNICO}

Em fevereiro de 2005, o MDS, através da SENARC, editou a sua primeira IO daquele ano, IO n⿳0 4/2005, estabelecendo procedimentos para correção de multiplicidades no Cadastro Único, resultado de novas auditorias internas realizadas sobre o mesmo. Em verdade, essa Instrução dá continuidade e amplia o escopo da IO n.ำ1/2004, já analisada acima, alcançando um maior número de ocorrências de dados repetidos. No mesmo período, fevereiro de 2005 , foi publicada a IO n.. 5, com procedimentos para a importação da base de dados do Cadastro Único - a Base Caixa - pelos municípios, para que estes pudessem "gerenciar" as informações das famílias inclusas no Cadastro. Trata-se de uma medida para atualização cadastral, mas não obrigatória, pois interessava apenas aos municípios que não estavam seguindo regularmente o procedimento de importação dos arquivos -retorno. A Base ora disponibilizada continha dados atualizados até 15 de dezembro de 2004, e os procedimentos de atualização só seriam funcionais na versão 5.0.1 do aplicativo de entrada de dados, portanto, antes de atualizar os dados era necessário atualizar o software. Caso a versão instalada fosse anterior à 4.8, era necessário dirigir-se à Caixa Econômica com medias virgens (quatro disquetes ou um $\mathrm{CD}$ ) e solicitar a gravação desta, e só após a sua instalação seria possível atualizar para a versão 5.0.1 através da internet, a partir do que se faria a importação dos dados. Orientou-se que, no caso de municípios sem o software do Cadastro, se fizesse o download do mesmo e o instalasse. Com o aplicativo instalado, o município deveria proceder à importação da Base Caixa, na qual estariam os dados mais atuais dos munícipes cadastrados, “considerando, também, as alterações de registro realizadas fora do Cadastramento Único como, por exemplo, aquelas feitas diretamente no cadastro do NIS/PIS”. (BRASIL, 2005g, item 3) Isso demonstra o desenvolvimento de um sistema de gestão de informações num grau de sofisticação técnica destoante da realidade vivida na maioria dos municípios brasileiros.

Ao orientar os municípios quanto aos procedimentos de atualização, essa IO (n.. 5/2005) expõe informações sobre as condições existentes para 
a operação do Cadastro Único. Embora fosse conhecido que todos os municípios já tinham dados inseridos na Base, a existência de diferentes versões do software instaladas demonstra a diversidade de situações em que ele operava, o que se traduz consequentemente em diferentes estágios de gestão e implementação dos programas sociais. Por outro lado, e de forma contraditória, pode-se observar que o mesmo documento presume que há entre os municípios certa uniformidade de infraestrutura tecnológica, definindo procedimentos comuns a todos eles. Ademais, a base de dados que pretende agrupar toda a população pobre do país continua fora do controle da Administração Pública da política social, sendo delegada e operada por uma instituição financeira; é a Base Caixa que corresponde à base de dados do Cadastro Único do Governo Federal. Por fim, a última informação se impõe como uma questão: até que ponto se materializa a equivalência entre NIS e PIS? A IO n.ำ 5 afirma que a Base Caixa contempla alterações extra CadÚnico, efetuadas sobre o "NIS/PIS”. (BRASIL, 2005g) Ao que se percebe, vigora ainda a ideia de se criar um sistema comum de identificação, mas, nesse caso, desvinculando o NIS do Cadastro Único, o que cria uma incógnita.

Em abril de 2005, divulgou-se a IO n.ำ 6, orientando os municípios à complementação dos dados das famílias oriundas do cadastro Bolsa Escola, CadBES, inseridas no CadÚnico. Para isso, foi disponibilizada a Base Caixa com dados atualizados até 28 de janeiro de 2005 , sobre a qual deveria se dar preferencialmente a complementação. Esse procedimento deveria também depurar os dados de eventuais multiplicidades cadastrais geradas na sobreposição dos registros. Para a complementação, foi criado um formulário específico, "caderno laranja”, facultando-se o uso do formulário avulso do CadÚnico, não sendo permitida, porém, a utilização do formulário padrão do Cadastro (“caderno azul”).

É com essa complementação que se iniciam as medidas de qualificação do Cadastro Único propriamente ditas, que se tornam mais visíveis a partir de maio de 2005, com a edição da IO n.․․ 7. Através dessa Instrução, o governo vai, pela primeira vez, deter-se na crítica às inconsistências dos dados do Cadúnico, e é exatamente aí que se adota o conceito de validação do cadastro, enquanto confirmação deste sobre si mesmo, não a partir de uma avaliação externa. A IO n. .7 resulta das análises do MDS sobre a Base Caixa de 28 de janeiro de 2005, visando localizar inconsistências tanto no preenchimento do formulário, com respostas conflitantes entre campos 
complementares, quanto incongruências entre a renda declarada e a aferida no cruzamento com a RAIS do Ministério do Trabalho. Para essa tarefa, foi desenvolvido um software específico: "Inconsistências do Cadastro Único", o qual posteriormente foi remetido aos municípios para que os gestores identificassem as famílias cujos dados apresentavam inconsistências e, assim, procedessem à sua correção, o que se daria através do software de entrada e manutenção de dados do Cadúnico.

O processo de gerenciamento da correção das inconsistências seguiria algumas etapas. Primeiro era necessário instalar o aplicativo e através dele solicitar um relatório dos registros inconsistentes, cuja dimensão variava entre os municípios. Esse relatório poderia ser impresso ou salvo no computador para visualização em tela. A partir daí, a verificação da correspondência ou não entre as informações presentes no relatório e os dados do cadastramento dar-se-ia diretamente no formulário do Cadastro Único arquivado pelo município ${ }^{65}$, e as alterações necessárias seriam feitas no software offline, podendo ser antecedidas de visita aos domicílios cadastrados. Os procedimentos eram semelhantes tanto para as inconsistências de informações quanto às de renda, sendo que, no segundo caso, o aplicativo específico deveria ser também utilizado na confirmação ou não da divergência entre a renda cadastrada e a aferida a partir do cruzamento com a RAIS; além disso, o prazo para a atualização destes registros era imediato, expirando em 31 de julho de 2005 . A IO nº 7 determinou que a "verificação e correção das inconsistências" deveria se dar prioritariamente sobre os registros anteriores ao Bolsa Família e na complementação dos dados do CadBES (BRASIL, 2005i, item IV), o que sugere que os principais problemas encontrados situavam-se no período compreendido entre outubro de 2001 e outubro de 2003, sendo, portanto, problemas acumulados durante a vigência dos programas ora "remanescentes", o que inclui também o PNAA, do governo de então.

O desenvolvimento de um instrumento adicional para o tratamento de inconsistências deve-se certamente ao elevado volume dessas inconsistências, identificado nas análises do MDS sobre o Cadastro Único, e a importância de sua superação para a consolidação do Cadastro e a pretendi-

65 Em atenção ao disposto no Decreto n. ${ }^{\circ} 5.209 / 2004$ (Art. 33, $\S 1^{\circ}$ ), toda a documentação referente ao cadastramento para o Bolsa Família deve ser arquivada por um prazo mínimo de cinco anos. 
da "expansão do Programa Bolsa Família". Ainda assim, o software offline pelo qual se fariam as alterações devidas não impediria o eventual registro de novos erros, por isso se fez necessária a implantação do mecanismo de validação eletrônica dos dados no processamento feito pela Caixa Econômica. Doravante, os registros que não apresentassem número de Cadastro de Pessoa Física (CPF) ou Título Eleitoral, além de preenchimento de todos os campos obrigatórios do formulário, seriam rejeitados. Esses passaram a ser os novos "critérios de validação" do cadastro, que funcionaram como um mecanismo de "crítica", possibilitando a admissão de dados já com requisitos mínimos de consistência, elemento fundamental para tornar o CadÚnico um instrumento confiável.

Concomitantemente à edição da IO n. .7 , o MDS publicou a Portaria no 246/2005, que aprovou o termo de adesão formal dos municípios ao PBF. Trata-se, em verdade, de um termo de adesão ao Bolsa Família e ao Cadastro Único, para cuja assinatura exigia-se do prefeito a designação de um gestor municipal para o Programa e a formalização de sua instância de controle social. Ou seja, num só instrumento, tentava-se solver ao menos três problemas: o comprometimento do município sobre as responsabilidades que lhes eram atribuídas na gestão do PBF e do Cadastro; a ruptura com a coordenação difusa dos programas sociais e do cadastramento de seus beneficiários no âmbito municipal e o reestabelecimento do controle social como um dos pilares da execução do Programa. A adesão, embora voluntária, tinha um prazo de 120 dias determinado para a sua realização e seria condição para tornar o município "elegível” a um eventual "recebimento de recursos financeiros para o desenvolvimento de sua capacidade de gestão do Programa Bolsa Família e do Cadastro Único”. (BRASIL, 2005e, Art. $5^{\circ}$ )

Um mês após a publicação dessa Portaria, em 20 de junho, a SENARC editou mais uma IO, a IO n.․ 8/2005, dessa vez para orientar os municípios sobre o tratamento das multiplicidades cadastrais identificadas em processo de auditoria interna sobre as folhas de pagamento dos programas de transferência de renda. ${ }^{66}$ A nova Instrução traz o conceito de "conversão de NIS", procedimento eletrônico pelo qual a Caixa Econômica desativa os NIS excedentes de uma mesma pessoa, vinculando-os a um só número, ou seja, o registro não desaparece, mas perde validade para efeito de pagamento de

66 Citado já na IO n. ${ }^{\circ} 7$ como estando em desenvolvimento (cf. item VIII, final). 
benefícios. Esse procedimento foi utilizado para corrigir as várias modalidades de NIS multiplicado com implicações nas folhas de pagamento, resultando em bloqueio e cancelamento de benefícios pagos indevidamente.

$\mathrm{Na}$ esteira desse conjunto de ações voltadas ao CadÚnico e ao Bolsa Família, o MDS instituiu, em julho de 2005, o boletim "Informe Bolsa Família”, uma publicação semanal direcionada aos gestores municipais do Programa. O Informe representou a construção de um canal permanente de comunicação ao município de todas as ações realizadas pelo gestor federal acerca do PBF e do Cadastro, uma espécie de ratificação e lembrete contínuo das orientações e mudanças realizadas por meio de Portarias e Instruções Operacionais e Normativas, notadamente as referidas ao processo de qualificação do CadÚnico, em curso desde o início de 2005. O primeiro boletim chamou a atenção das prefeituras quanto ao instrumento de adesão ao Bolsa Família instituído pela Portaria n⿳0 246/o5, os requisitos para aderir e o limite do prazo estipulado para fazê-lo. A criação desse instrumento de comunicação tanto reforçava as ações do MDS para qualificação do Cadastro e da gestão do PBF, quanto respondia ao antigo problema de falta de comunicação, apontado desde a criação do Cadúnico como um dos fatores que dificultavam sua implantação.

Dias após a publicação do primeiro Informe, o MDS publicou a Portaria n. ${ }^{\circ}$ 36o/2005, estabelecendo os critérios para transferência de recursos aos municípios, confirmando o que fora previsto na portaria que formalizou a adesão. (BRASIL, 2005e, Art. $5^{\circ}$ ) Dentre as justificativas apresentadas, no preâmbulo da nova portaria, para essa transferência de recursos, merecem destaque: "a necessidade de dotar os municípios de condições para a operação das atividades de cadastramento, manutenção do Cadastro Único [...] e atualização das informações socioeconômicas e de identificação das famílias cadastradas” (BRASIL, 2005c); as recomendações do TCU para "repasse de recursos do Governo Federal aos municípios, para a operação do Cadastro Único" e a "necessidade de disciplinar e estabelecer requisitos para a validação das informações contidas no Cadastro Único". (BRASIL, 2005C) Estão aí postos simultaneamente o reconhecimento da falta de condições dos municípios em cumprir as responsabilidades que lhes eram atribuídas na execução do CadÚnico, o peso institucional do TCU para que esse reconhecimento se desse e a opção por transformar o CadÚnico num instrumento de gestão confiável para as políticas sociais. 
Segundo a Portaria $\mathrm{n}^{\circ} 360 / 2005$, no Art. $1^{\circ}$, o repasse de recursos se daria apenas em 2005 e se faria mediante a realização de algumas atividades por parte dos municípios: "atualização dos dados das famílias já inscritas no CadÚnico"; complementação dos dados do CadBES e inclusão de novas famílias com "perfil PBF", quando o número de inscritos estivesse abaixo das estimativas para o município. (BRASIL, 2005c, Art. $2^{\circ}$, $\$ 2^{\circ}$ ) Para cada cadastro válido transmitido pelo município até o último dia daquele ano (2005), seriam repassados $\mathrm{R} \$ 6$, oo. Para fins de remuneração dos municípios, a primeira verificação de validade se daria em 31 de julho e se repetiria regularmente a cada dois meses. O repasse de recursos seria parcelado, iniciando-se já com a transferência de $20 \%$ do valor estimado no momento da adesão do município. A Portaria n. ${ }^{\circ} 360$, no Art. $7^{\circ}$, previu também o repasse para os estados, desde que estes aderissem ao "processo de atualização cadastral" e que a totalidade de seus municípios também o fizesse. Como essa portaria saiu a pouco menos de dois meses após a Portaria n.ำ246/2005 (adesão), percebe-se que ela funciona como um instrumento de estímulo à adesão, pelo que se pode deduzir que, estando a quase metade do prazo estipulado para a finalização do processo, os resultados não eram ainda satisfatórios. Tanto o é que o mesmo documento traz a determinação de bloqueio aos benefícios pagos por meio do CadBES para os dados cadastrais que não fossem atualizados até outubro. (BRASIL, 2005c, Art. 10)

Isso se reforça no segundo número do Informe Bolsa Família, 14 de julho de 2005, que se apresenta com o título "Municípios receberão recursos para atualizar Cadastro Único”, explicitando em seu subtítulo as condições para essa remuneração: "Municípios que assinarem o Termo de Adesão serão remunerados em R \$ 6 a cada atualização no Cadastro Único”. O Informe PBF n.. 2 detalhou o conteúdo da Portaria n⿳0 36o/2005, destacando a importância de se realizar o cadastramento de todas as famílias com renda per capta até meio salário mínimo, ponderando que a remuneração de novos cadastros se faria exclusivamente aos municípios cuja cobertura do Bolsa Família estivesse abaixo das estimativas de pobreza. (BRASIL, 2005n)

O Informe n.. 3, de 25 de julho de 2005 [errata], alerta para o final do prazo para atualização das informações dos registros com renda declarada divergente da apurada junto à RAIS, orientando os municípios a priorizarem as famílias beneficiárias do Bolsa Família, para o que disponibilizaria uma listagem específica das famílias nessa condição. Abriu-se a possibilidade de ampliar o prazo de envio das informações até 3 o de outubro, vincu- 
lando-o ao limite para a complementação dos dados do CadBES, mas sem a utilização do aplicativo específico para o tratamento de inconsistências. Esse Informe traz uma observação em destaque, de que cada município tem como referência um número estimado de famílias pobres, e assim, "se uma família que está fora dos critérios do programa está recebendo benefícios, outra família deve estar fora". (BRASIL, 20050) É como se a estimativa do Governo Federal desse realmente conta do número exato de pobres dos municípios e como se o benefício do Bolsa Família suprisse as necessidades das famílias nessa condição.

Os dois números seguintes do Informe $\mathrm{PBF}, \mathrm{n} .^{\circ} 4 \mathrm{e} 5$, tratarão respectivamente do papel do gestor municipal do Bolsa Família - alertando mais uma vez para o prazo de adesão - e da importância da instância de controle social no acompanhamento do Programa, notadamente no processo de seleção de beneficiários, com o objetivo de "fazer com que os benefícios efetivamente cheguem às famílias que atendem aos critérios definidos na legislação que criou e regulamentou o Programa”. (BRASIL, 2005q) Essas questões serão retomadas na IO n. ${ }^{\circ} 9 / 2005$, editada poucos dias depois. Dentre as finalidades dessa Instrução está a de orientar ao correto preenchimento dos documentos para a adesão ao Bolsa Família e ao CadÚnico, reiterando os procedimentos necessários para a conclusão do processo. Num dos itens da IO n.ำ 9, reproduz-se o conteúdo do Informe PBF n.o 4, de 28 de julho de 2005, reafirmando a relevância do cargo de gestor municipal do Programa e sugerindo que seja designado o secretário municipal de assistência social para ocupá-lo. Quanto à instância de controle social, orienta-se a edição de ato do prefeito (portaria ou decreto) para a respectiva designação, o qual deve seguir anexo aos demais documentos de adesão.

A persistência do MDS sobre a necessidade de formalização da adesão pode estar indicando, dentre outros aspectos, uma certa resistência dos municípios em comprometer-se com a gestão do Bolsa Família e do CadÚnico, afinal, a etapa mais difícil, a execução de fato, estaria sob sua responsabilidade. Se não isso, pode estar demonstrando que o tempo necessário à adaptação dos municípios à nova estrutura de gestão era muito superior ao estimado pelo Governo, inclusive pela dificuldade de compreensão em profundidade da importância que tinha essa gestão para a efetivação ou "efetividade" da política social de transferência de renda almejada pelo Governo Federal, tanto assim que reiteradamente o MDS alerta para o grau de poder delegado ao gestor municipal do Programa, sugerindo um perfil qualificado 
para a ocupação desse cargo, preferencialmente um membro do alto escalão da administração municipal.

Isso certamente não foi cogitado quando da determinação pela adesão formal (BRASIL, 2005e), e agora tornava-se quase um óbice à modernização da gestão do Bolsa Família, condicionada à qualificação da base de dados do CadÚnico. Assim, seguidamente, buscar-se-á estimular a adesão, e a medida mais destacada para isso será a remuneração dos municípios para a execução do CadÚnico. A exemplo disso, o Informe PBF n. 으, de 11 de agosto de 2005, anunciará que o repasse de recursos aos municípios foi iniciado, contemplando já 31 municípios dentre os 1.439 termos de adesão recebidos pelo Ministério. Esse é um número ínfimo de aderentes, alcançando pouco mais de $1 / 4$ do total dos municípios brasileiros, e considerando que mais da metade do prazo já se havia transcorrido, é também um indicador de que a adesão integral demandaria pelo menos o dobro do tempo previsto. Ademais, também o número de municípios cuja adesão já havia sido deferida é extremamente baixo, cerca de $2 \%$ do total de termos entregues. Isso sugere que o próprio MDS não dispunha ainda de capacidade para atender à demanda que estava criando com os novos procedimentos.

No Informe $\mathrm{PBF}^{\mathrm{0}}$ 7, de 22 de agosto de 2005, anuncia-se a descentralização da gestão dos benefícios do PBF, propiciada pela adesão dos municípios, "medida [que] permitirá aos gestores municipais do programa administrar, em sua própria cidade, a transferência de renda às famílias participantes do programa”. (BRASIL, 2005s) A expectativa é que, com a descentralização, os municípios passem a exercer algum controle sobre a gestão de benefícios, podendo realizar bloqueio, desbloqueio ou cancelamento dos mesmos. A inclusão de novos beneficiários, embora seja parte da gestão (a principal), seria mantida tarefa exclusiva ao MDS (SENARC), sob a justificativa da necessidade de "acompanhamento e compatibilização das estratégias de expansão” do Bolsa Família. Interpreta-se do disposto nesse boletim que a gestão não apenas é descentralizada, mas fragmentada, onde os municípios se responsabilizam pelo monitoramento da condição de pobreza, pelo ordenamento interno do CadÚnico, ratificando a classificação estabelecida pela União.

Ao final do mês de agosto (2005), publicou-se a IO no ${ }^{\circ}$, com esclarecimentos sobre as marcações de "ativo" (registro validado) e "inativo" (registro repetido), atribuídas aos registros dos domicílios no CadÚnico, decorrentes da identificação de domicílios em multiplicidade. Nos casos 
em que um mesmo responsável respondia por mais de um domicílio, marcava-se como "ativo" o registro mais atual, e como "inativo" os demais. Foi disponibilizado um relatório dos registros em multiplicidade via internet para que os municípios realizassem as alterações pertinentes no CadÚnico. Esse relatório seria disponibilizado periodicamente, compilando as alterações feitas pelos municípios em relação à correção de inconsistências e multiplicidades.

Esse é também o momento em que se realiza a transição de tecnologia do software de entrada e manutenção de dados: a versão 6.o incorporaria novas funcionalidades, maior interatividade com o usuário e melhor dinâmica de tratamento dos dados cadastrais. A IO n.ำ10/2005 informa que o novo aplicativo estaria disponibilizado para download no site da Caixa Econômica, com seu respectivo manual de operação, e que a partir de 19 de setembro 2005 seria iniciada uma dinâmica progressiva de capacitação para os gestores municipais e estaduais do Bolsa Família e CadÚnico para a sua utilização. O Informe PBF n. ํ 8, publicado um dia após a IO nํำ10/2005, trata da prorrogação do prazo para o envio da remessa periódica de informações sobre a frequência escolar, ressaltando que as condicionalidades "são um estímulo para garantir a participação efetiva das famílias no processo educacional e nos programas de saúde, que promovem a melhoria das condições de vida da população".

É no Informe seguinte, n.ำ 9, de 6 de setembro de 2005 , que se discutirá a nova versão do software do CadÚnico, versão 6.o. O foco do Informe está exatamente nas novas funcionalidades do aplicativo, como instalação em rede, tratamento de multiplicidades e a geração de relatórios diversificados, com destaque especial à marcação dos domicílios como "ativo" ou "inativo", dispensando o recurso aos relatórios disponibilizados pelo MDS para as versões anteriores e tornando mais ágil o processo de correção de multiplicidades. Esse Informe traz (como todos os anteriores) o lembrete do final do prazo para a adesão municipal ao Bolsa Família, em 20 de setembro, informando ainda que 2.549 municípios já haviam solicitado a adesão e que 649 deles já estavam recebendo os recursos pertinentes. Há um mês do último balanço, verifica-se que houve uma melhora sensível nas adesões, alcançando cerca de $46 \%$ dos municípios, com melhora também no retorno dado pelo MDS, que saiu de parcos $2 \%$ para $25,5 \%$. Ambos, porém, com clara demonstração de que não alcançariam a totalidade pretendida nas duas últimas semanas restantes do prazo estipulado. 
O próximo boletim a tratar da adesão será o Informe no 11, publicado em 19 de setembro 2005, véspera do prazo limite. Em termos gerais, ele transcreve o que fora publicado nos Informes n. ${ }^{\circ} 1$ e n.. 2 , com requisitos e procedimentos para a adesão, bem como informando sobre a remuneração para os cadastros válidos exclusivamente para os municípios aderentes. No dia seguinte, porém, publicou-se o Informe $\mathrm{n} .{ }^{\circ} 12$, informando a prorrogação do prazo de adesão até 31 de outubro de 2005 . No Informe seguinte, no ${ }^{13}$, de 27 de setembro de 2005 , o foco será a capacitação dos gestores municipais para a gestão do CadÚnico e dos benefícios, mas alude-se brevemente à adesão, para informar aos gestores e prefeitos que "não é preciso pagar ou contar com a ajuda de consultores para ter acesso às informações sobre o Termo de Adesão do seu município”. (BRASIL, 2005x) Deduz-se daí que àquela altura ainda havia municípios sem a correta compreensão do processo de qualificação em curso, o que pode estar entre as causas da não adesão no tempo estimado. Nesse sentido, o Governo Federal lançou uma campanha de mobilização para a atualização cadastral, convocando a população pobre a procurar as prefeituras e regularizar o seu cadastramento.

Em 28 de outubro, no Informe n. ${ }^{\circ}$ 19, o MDS (SENARC) noticiou que 5.174 municípios (93\%) já teriam enviado o Termo de Adesão e que, destes, 2.642 (pouco mais de metade [51\%]) já estariam recebendo os recursos provenientes da atualização cadastral. O objetivo principal do boletim, no entanto, era mais uma vez os municípios quanto à finalização do prazo, prevista para o dia 31. Contudo, no Informe n. ${ }^{\circ}$ 2O, de $1^{\circ}$ de novembro, há um destaque para o preenchimento do Termo de Adesão, o que demonstra ainda a não integralidade de adesão e a flexibilidade dada a esse processo. O tema principal desse boletim, no entanto, é a "campanha de atualização cadastral 'Bolsa Família Chama”, voltada à população de baixa renda e para a qual os municípios deveriam se instrumentalizar, pois tinha-se a expectativa de uma elevada demanda. Esse tema retorna no Informe seguinte, n. ${ }^{21}$, de 10 de novembro de 2005, complementando o tema principal (a "transferência de recursos para a atualização cadastral"), mais uma vez nos mesmos moldes do Informe PBF n. ${ }^{\circ}$ 2, publicado logo após a edição da Portaria n. ${ }^{\circ}$ 36o/2005 (12 de julho), que instituiu o repasse de recursos, principal estratégia para estímulo à adesão dos municípios à qualificação do Cadúnico.

Em novembro de 2005, o MDS editou a Portaria n. ${ }^{\circ}$ 555, disciplinando os procedimentos de gestão de benefícios do $\mathrm{PBF}$, que dar-se-iam mediante 
uso do Sistema de Gestão de Benefícios. Essa portaria definiu claramente que as atividades de gestão competem exclusivamente ao Ministério, através da SENARC, e ao município, na pessoa do gestor local do Programa. Para este, a utilização direta do Sistema de Gestão condicionar-se-ia ao deferimento de sua adesão ao PBF. Foram elencadas, como sendo de gestão, dez atividades:

I - Bloqueio de benefícios; II - Desbloqueio de benefícios; III - Suspensão de benefícios; IV - Reversão de suspensão de benefícios; V - Cancelamento de benefício básico; VI - Reversão de cancelamento de benefício básico; VII - Cancelamento de benefícios variáveis; VIII - Reversão de cancelamento de benefícios variáveis; IX - Cancelamento de benefícios; e X - Reversão de cancelamento de benefícios. (BRASIL, 2005d, Art. $2^{\circ}$ )

Note-se que a concessão de benefícios não foi incluída dentre essas atividades, diferente do que se viu no Informe PBF n. . 7, 22 de agosto de 2005, quando se afirmou que "A Gestão de Benefícios é composta por todas as atividades que envolvem movimentação no pagamento dos benefícios [...], desde as ações de inclusão das famílias no Programa, até a realização de bloqueios, desbloqueios e cancelamentos”. (BRASIL, 2005s) Essa talvez tenha sido uma estratégia para evitar confusão ou para facilitar a compreensão pelos gestores municipais, pois essa seria uma dimensão da gestão mantida sob a competência exclusiva da SENARC, conforme o próprio boletim $\mathrm{n}^{\circ} 7$ definiu, porque condicionada aos limites orçamentários. Isso se confirmará na publicação do Informe PBF n.. 24, 2 de dezembro de 2005, no qual se afirma que a edição da Portaria n. ${ }^{\circ}$ 555/2005 permitirá ao MDS a implantação do sistema de gestão descentralizado, destacando o papel exclusivo do Ministério na concessão de benefícios. Mas nem todas as atividades previstas na Portaria n.ำ 555 foram de imediato colocadas à disposição dos municípios, pois seria necessário realizar adaptações nos sistemas eletrônicos da Caixa Econômica, pelo que adotaram-se procedimentos transitórios, limitando à SENARC a operação integral do Sistema de Gestão.

Ainda em novembro (2005), a SENARC publicou a IO n.. 11 , divulgando os resultados de nova auditoria interna realizada sobre o CadÚnico, considerando os dados sistematizados até 31 de agosto daquele ano, o que levou a uma série de bloqueios de benefícios, cuja listagem foi disponibilizada aos municípios nas agências da CEF. Essa forma indireta de acessar os resultados confirma que o Sistema de Gestão de Benefícios ainda não comportava todos os procedimentos necessários para a realização das atividades 
requeridas, do contrário, pode-se supor que a geração de relatório específico informaria ao município a situação dos benefícios, como se fez em relação à condição de "ativo" ou "inativo" atribuída aos domicílios, inclusive porque essa nova auditoria já se dava sobre uma base de dados relativamente depurada de inconsistências e multiplicidades, verificadas em outras ações do MDS, como se percebe, por exemplo, em um dos quesitos da auditoria, que visava "Identifica famílias (Responsáveis Legais) que, além de terem sido excluídas pelas prefeituras ainda se encontravam com mais de um cadastro no CadÚnico" (BRASIL, 2005m, item 2). De todo modo, essa auditoria punha já em prática atividades de gestão de benefícios postuladas na Portaria n. ${ }^{\circ}$ 555/2005, no Artigo 24, naquilo que competia à SENARC, e solicita aos municípios que procedam de igual forma naquilo que lhes for pertinente, a exemplo do desbloqueio de benefícios quando couber, com a perspectiva de que, a partir de janeiro de 2006, os procedimentos utilizados fossem definitivamente incorporados aos softwares do Cadúnico.

\section{CONSOLIDAÇÃO DA NOVA ESTRUTURA OPERACIONAL COM INTEGRAÇÃO DAS INFORMAÇÕES DO PÚBLICO- -ALVO DA ASSISTÊNCIA SOCIAL}

Em dezembro de 2005, o MDS divulgou o Informe PBF n.. 27, com o balanço das ações realizadas sobre o PBF naquele ano. Ali se destaca inicialmente o cumprimento da meta de cobertura para o ano, que era de 8,7 milhões de famílias beneficiárias. Em seguida, põe-se a adesão, através da qual se definiu formalmente o papel de cada ente federado na gestão do programa e do CadÚnico. Segundo esse Informe, 5.545 municípios (ou 99,4\%) já teriam enviado o Termo de Adesão, dos quais 5.230 (94\%) já teriam a adesão deferida, e mais de 4.800 (86\%) estariam já recebendo os recursos concernentes à atualização cadastral. Junto à gestão de benefícios, o tópico da atualização cadastral tem o destaque principal, pois aí se incluem a nova versão do software offline, já posta em uso por cerca de dois mil municípios; o total de atualizações até então efetuadas no Cadúnico (40\%); os mais de 290 mil bloqueios realizados a partir das auditorias do MDS e a complementação de dados de cerca de 350 mil beneficiários advindos de programas remanescentes. Ademais, expuseram-se as perspectivas para o ano seguinte (2006), dentre as quais se destaca a melhoria da comunicação, inclusive diretamente entre o governo e os beneficiários, para o que se previu a publicação da "agenda de compromissos da família". (BRASIL, 2005cc) 
Após esse balanço, uma nova medida foi adotada ainda em 2005: a integração entre os programas Bolsa Família e PETI, por meio da Portaria no 666/2005 do MDS, documento que punha em articulação duas secretarias do Ministério: Renda de Cidadania (SENARC) e Assistência Social (SNAS). Note-se que, embora a integração se dê ao final do ano (28 de dezembro de 2005), as atividades de gestão de benefícios do Bolsa Família postas em vigência anteriormente já contemplavam a verificação de trabalho infantil na família, podendo resultar em bloqueio e cancelamento dos benefícios. Diferente do que ocorreu no caso dos programas remanescentes, essa medida não significou a unificação dos programas, mas a racionalização dos seus procedimentos de gestão. A inclusão de novas famílias que se enquadravam na situação de trabalho infantil dar-se-ia a partir do CadÚnico, em duas modalidades: no PBF, caso a renda per capta não ultrapassasse $\mathrm{R} \$ 100,00$ (SENARC) e no PETI, em caso contrário (SNAS). Aquelas famílias já beneficiárias do PETI que atendessem aos critérios do PBF seriam gradualmente transferidas para este, inclusive contempladas com o "Benefício Variável Extraordinário", quando pertinente, procedimento condicionado à disponibilidade orçamentária do Programa. Ademais, as famílias em situação de trabalho infantil beneficiárias do PBF, além de cumprir as condicionalidades desse Programa, deveriam inserir suas crianças nas atividades socioeducativas e de convivência - "jornada ampliada" - do PETI (BRASIL, 2005a, Art. 13), sob acompanhamento da SNAS. Os municípios tiveram o prazo até 31 de março de 2006 para a inclusão de todas as famílias beneficiárias do PETI na base de dados do CadÚnico. (BRASIL, 2005a, Art. 12)

Para os fins da presente análise, o aspecto mais importante a se observar nessa integração é a importação, para o corpo de dados do CadÚnico, de mais uma parcela da população presumidamente pobre. A adoção de mais uma medida em favor da unificação efetiva de um cadastro específico dessa população. Além disso, essa medida vem ajudar na correção de inconsistências nas informações, pois os casos em que as famílias acumulavam benefícios dos dois programas (PETI e PBF) seriam agora mais facilmente identificados, submetidos às mesmas auditorias a que estavam os demais beneficiários do Bolsa Família. Ainda em dezembro de 2005 (dia 29), o MDS editou nova Portaria, no 672, alterando o conteúdo das Portarias n. ${ }^{\circ} 246 / 2005$ e n. ${ }^{\circ}$ 360/2005, que tratam da adesão dos municípios ao PBF e do apoio financeiro do Governo Federal para a manutenção do CadÚnico, respectivamente, além do Art. 26 da Portaria n.ํ5 555/2005, prorrogando o 
prazo para bloqueio dos benefícios concedidos através do CadBES para $1^{\circ}$ de março de 2006.

Na Portaria n. 672/2005, o prazo para adesão ao PBF e ao CadÚnico foi prorrogado até 28 de fevereiro de 2006 , data igualmente fixada para a atualização e complementação cadastral com remuneração, incluindo-se agora também os cadastros concernentes ao PETI. Essas informações foram compiladas e comunicadas aos municípios através do Informe PBF nํ29, de 5 de janeiro de 2006, mas, no que se refere especificamente à inserção das famílias no CadÚnico, a SENARC e a SNAS editaram a Instrução Operacional Conjunta (IOC) n.. ำ em 14 de março 2006. Essa Instrução destaca que, a partir da Portaria no 666/2005, "para recebimento do benefício do PETI ou do PBF, é necessário que o beneficiário e toda sua família estejam cadastrados no Cadastro Único" (BRASIL, 2006f), alertando que o prazo de inclusão de dados ou atualização remunerada se encerraria no último dia daquele mês. ${ }^{67}$ A IOC nํำ $1 / 2006$ esclarece que o cadastramento é direcionado especialmente para as famílias beneficiárias do PETI que ainda não estão inclusas no CadÚnico e para aquelas que, estando em situação de trabalho infantil, ainda não são beneficiárias desse programa. Quanto à remuneração, reitera que a cada cadastro novo ou atualizado na base do CadÚnico o município fará jus a $\mathrm{R} \$ 6$, oo, tendo um limite estabelecido pela estimativa de famílias com o perfil definido, segundo a SNAS.

A primeira IO especificamente da SENARC publicada em 2006, IO n. ${ }^{-12}$ 12006, ratifica as ações realizadas em 2005. Essa Instrução comunica que o MDS implantou definitivamente os mecanismos de auditoria no Sistema de Gestão de Benefícios (SIBEC) ${ }^{68}$ sendo que, daí em diante, algumas atividades de gestão já poderão ser realizadas diretamente no software offline do CadÚnico. O principal avanço anunciado é de que a integração entre os sistemas de gestão e de cadastramento permitirá que as alterações cadastrais tenham "repercussão automática" sobre a folha de pagamentos dos programas de transferência de renda. Os novos procedimentos darão celeridade e eficácia na troca de informações entre as bases de dados da Caixa Econômica e dos municípios na forma seguinte: o gestor local do PBF

67 Essa data foi fixada pela Portaria n. ${ }^{\circ}$ 68/2006, como se verá mais à frente.

68 A sigla "SIBEC" foi atribuída ao Sistema de Gestão de Benefícios pela Caixa Econômica, que o desenvolveu, tratando-o por Sistema de Benefícios do Cidadão. Inicialmente, o MDS o identificava por "SCB", como se observa na IO n. ${ }^{\circ} 12 / 2006$, mas findará por tratá-lo também como SIBEC, mantendo a denominação "Sistema de Gestão de Benefícios". 
realiza as alterações no Cadastro e envia à Caixa, esta processa os dados e remete ao município o "arquivo-retorno"; simultaneamente, as alterações que implicam na modificação da composição do benefício são remetidas ao SIBEC e submetidas, assim, ao mecanismo de "reavaliação de benefícios financeiros", que verifica as condições de elegibilidade das famílias beneficiárias, com aplicação das respectivas atividades de gestão, redundando na atualização da folha de pagamentos (Figura 1).

Figura 1 - Fluxo de informações Cadúnico-SIBEC (2006)

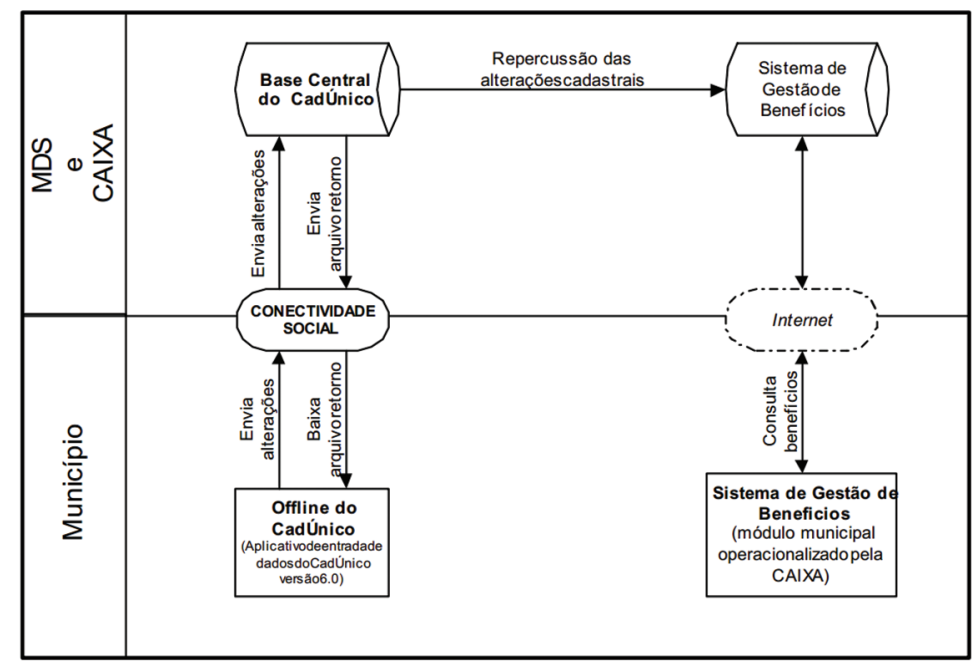

Fonte: Brasil (2006e).

O funcionamento dessa estrutura estava condicionado à utilização da nova versão do software offline (versão 6.o) pelos municípios, o que não se dava ainda em mais de metade dos casos, como se verifica no Informe n. 28 do Bolsa Família, de 29 de dezembro de 2005 , que informou que, ao final de 2005, cerca de 2,6 mil municípios tinham o aplicativo atualizado, tendo sido ampliado o prazo para a sua instalação pelos municípios até 28 de fevereiro de 2006. Como descrito acima, após a integração dos programas Bolsa Família e PETI (BRASIL, 2005a), procedeu-se à dilatação de prazos antes fixados até o final daquele ano (2005). A Portaria n.. 68, de 8 de março de 2006, reformulará o cronograma de prazos para adesão dos municípios ao PBF e CadÚnico e para a remuneração das atividades de atualização cadastral, ambos até 31 de março de 2006; para o bloqueio de benefícios con- 
cedidos através do CadBES, cujo cadastro não fora complementado pelos municípios, dá-se o dia $1^{\circ}$ de abril de 2006. (BRASIL, 2005dd)

O Informe PBF n.․ 33, de 22 de março de 2006, esclarece que a causa dessas reiteradas prorrogações de prazo é a existência de "falhas operacionais no processo de atualização". (BRASIL, 2006h) O elevado volume de dados enviados pelos municípios estava acima da capacidade de processamento do sistema do CadÚnico, operado pela Caixa Econômica. Em conta disso, o intervalo entre o envio dos dados à base central e a devolução do arquivo-retorno aos municípios, estimado em até 48 horas, chegou a alcançar 20 dias. Além disso, registrou-se também a "ocorrência de rejeições 'não esperadas"”. A explicação posta no boletim para esse fato é a de que a base central de processamento de dados da Caixa Econômica, além dos dados do CadÚnico, opera também as bases do FGTS, PIS/PASEP, CadSUS e outros. Por regra de segurança, as alterações cadastrais só eram permitidas ao agente que inseriu os dados, assim, se originalmente os dados de um determinado cadastro foram inseridos por agente diverso do gestor municipal do PBF, as alterações solicitadas por este eram rejeitadas. Esse é um detalhe complexo do sistema, que, à primeira vista, não permite compreender satisfatoriamente o seu funcionamento, afinal, quem insere dados específicos dos beneficiários dos programas de transferência de renda é o município. Por isso, é necessário remontar ao início da construção da base de dados de alguns desses programas.

Como se viu muito anteriormente, para alimentação inicial da base do CadBES (2001), a CEF atribuiria um NIS a cada registro, código equivalente ao número do PIS. A geração de um novo número se daria exclusivamente nos casos em que as pessoas cadastradas não dispusessem desse registro. Logo, parte dos dados que estavam sendo complementados em 2006 tomava por referência dados do mercado de trabalho formal e, por conseguinte, do Ministério do Trabalho. De forma semelhante, a base de dados do Bolsa Alimentação tinha referência no CadSUS, submetido, portanto, ao controle do Ministério da Saúde. Assim, sempre que o município tentava alterar esses dados, tinha o seu acesso negado. A solução encontrada foi quebrar a regra de exclusividade, dando acesso livre e prerrogativas para realizar alterações aos diversos órgãos usuários das bases de dados da Caixa Econômica. Os municípios teriam conhecimento das alterações mais recentes importando o "arquivo-remessa", procedimento previsto para após a instalação de uma versão mais avançada do aplicativo off-line: a versão 7.0. 
É também no ano 2006, que o critério de elegibilidade do PBF-leia-se, a renda familiar per capta - sofrerá a sua primeira alteração. O Decreto n. - $^{-}$ 5.749 , de 11 de abril daquele ano, alterou os valores de referência para identificação das famílias pobres e extremamente pobres para $\mathrm{R}$ \$120,00 e R \$ 60,00 , respectivamente. Junto à inclusão dos beneficiários do PETI, esse fato será fundamental para o alcance da meta estabelecida para o Bolsa Família em 2006, de alcançar 11,2 milhões de famílias, tendo em conta que o Programa encerrou o ano 2005 com 8,7 milhões de beneficiários. (BRASIL, 2007f) Mas, considerando o conteúdo da edição n. ${ }^{\circ} 36$ do Informe PBF, de 17 de abril de 2006, a essa época os municípios ainda não tinham claro que a alimentação e a atualização do Cadúnico deveriam ser um processo contínuo, o que era um problema causado, em parte, pelo fim da remuneração para a realização desse processo. Por conta disso, a SENARC solicitou dos municípios a continuidade das atividades e informou que se encontravam em estudo "formas de incentivar e viabilizar a ação permanente de atualização cadastral e de acompanhamento das famílias, considerando alguns critérios como o percentual de cadastros válidos do município”. (BRASIL, 2006i) Por outro lado, ao alertar as prefeituras para evitarem enviar dados de um mesmo domicílio mais de uma vez, antes do recebimento do arquivo-retorno, esse boletim ( $\left.\mathrm{n}^{\circ} 36\right)$ trouxe uma informação adicional ao bojo das dificuldades ainda enfrentadas para a consolidação da consistência do CadÚnico: a demora no processamento dos dados na base da Caixa Econômica confundia alguns gestores, levando-os a postar mais de uma vez os mesmos dados, o que levava fatalmente à produção de novas multiplicidades.

$\mathrm{Na}$ tentativa de resolver essas contínuas dificuldades, foi desenvolvida mais uma versão do software offline do CadÚnico, versão 6.o.2, que, segundo consta no Informe PBF n. ${ }^{\circ}$ 37, de 20 de abril de 2006, "corrige problemas identificados nos últimos meses” (BRASIL, 2006j), principalmente "problemas de rejeição de cadastros" (BRASIL, 20061), o que tornou a sua utilização obrigatória no processo de atualização cadastral a partir do mês seguinte (maio). Quanto à perspectiva de incentivo permanente à operação do CadÚnico, a proposta se materializou em parte na Portaria n. ${ }^{\circ} 148$, de 27 de abril de 2006, a partir da qual o apoio financeiro aos municípios se daria também durante aquele ano e não se limitaria mais à correção de inconsistências cadastrais, mas subsidiaria a manutenção do Cadastro e a gestão do Bolsa Família. Trata-se, em verdade, da criação de um mecanismo 
de mensuração do desempenho dos municípios na gestão do PBF (BRASIL, 2006k): o IGD, já anteriormente citado, do PBF.

A Portaria estabeleceu um valor de referência por cada família beneficiária do PBF, R \$ 2,50, mas esse valor constitui apenas um dos componentes para o cálculo dos recursos a serem transferidos, os quais serão o produto do valor de referência multiplicado pelo IGD, um índice sintético composto por dois indicadores específicos: o Indicador do CadÚnico (ICadÚnico), que corresponde a uma média simples entre o percentual de cadastros válidos, frente ao número estimado de famílias com perfil CadÚnico e a atualização cadastral, na qual se verifica o número de cadastros atualizados em razão do número de cadastros válidos na base; e o Indicador de Condicionalidades (ICondicionalidades), dada pelo acompanhamento das condicionalidades do Bolsa Família, com uma taxa extraída a partir das informações fornecidas sobre saúde e educação. (BRASIL, 2006c) ${ }^{69}$

» Cálculo IGD: [IGD = ICadÚnico + ICondicionalidades /2]

» Cálculo recurso por município: [IGD x R \$ 2,50 x nº famílias PBF]

Segundo a Portaria nº 148/2006, a atualização cadastral corresponderia à alteração realizada, num prazo máximo de 24 meses, em pelo menos uma de cinco variáveis: “a) endereço domiciliar; b) renda familiar; c) inclusão de membros na família; d) exclusão de membros na família; e e) mudança de responsável legal”. (BRASIL, 2006c, Art. 2º, $\mathrm{I}^{\circ}$ ) Observe-se que, a partir desse momento, a gestão do CadÚnico e a gestão do Bolsa Família passam a ter pesos equivalentes no repasse de recursos do Governo Federal para os municípios. Reforça-se não apenas a necessidade de manutenção do CadÚnico, mas também o monitoramento da confirmação da condição de pobreza dos beneficiários, dada principalmente pelo cumprimento das condicionalidades (o que poderia levar ao remanejamento da localização do NIS na estrutura do Cadastro, com as atividades de gestão no SIBEC, e simultânea "repercussão automática" sobre a folha de pagamentos do PBF). Isso se verificará, por exemplo, ao final de 2006, quando o Boletim do PBF n⿳0 6o, 18 de dezembro de 2006, informará o envio de notificação a mais de 258 mil famílias que teriam descumprido os seus "compromissos" com o Programa, incluindo casos de advertência $(78,17 \%)$, bloqueio $(22,81 \%)$ e sus-

69 Ver: Art. $1^{\circ}, \S 2^{\circ}$ e Anexol. 
pensão de benefícios (o,02\%). (BRASIL, 2006m) No mês de julho (2006), a Portaria no 148/2006 sofreu algumas modificações, feitas através da Portaria n. $.256 / 2006$, dentre as quais se destaca a ratificação do prazo máximo de 24 meses para atualização ou confirmação cadastral, sob pena de invalidação dos dados (BRASIL, 2006d, Art. $3^{\circ}$ ), e o acréscimo da frase "no limite da estimativa de famílias pobres publicada pelo MDS" aos parágrafos $1^{\circ} \mathrm{e}$ $2^{2}$ do Art. $3^{\circ}$, que tratam dos critérios de cálculo do IGD. (BRASIL, 2006d, Art. $1^{\circ}$ ) Essas alterações reforçam mais uma vez o papel do gestor municipal no monitoramento das famílias pobres de seu território e simultaneamente delimitam o alcance desse monitoramento para fins de remuneração do município: o contingente de pobres estimado pelo MDS em função das estatísticas oficiais. Meses à frente, em janeiro de 2007, o MDS ampliará a vigência do IGD até o final deste ano. (BRASIL, 2007b)

\section{AVALIAÇÃO DO CADASTRO COMO UMA BASE DE DADOS CONFIÁVEL SOBRE OS POBRES}

Em novembro de 2006, o TCU publicou o seu último relatório de monitoramento da auditoria realizada sobre o CadÚnico em 2002. O monitoramento se deu entre 27 de março e sete de abril de 2006 (com inserção de novas informações até a composição final do relatório), através de pesquisa postal e documental, visitas a doze municípios nos estados de Rio Grande do Sul, Minas Gerais, Bahia e Sergipe e cruzamento das informações do CadÚnico referentes ao Rio Grande do Norte (estado tomado como referência na auditoria em 2002) com outras bases de dados - SISOBI e SISBEN. Foram entrevistados gestores, cadastradores e famílias beneficiárias, sendo que, para estas, aplicou-se um "roteiro de verificação das informações contidas na base do Cadúnico", visitando 732 domicílios, dos quais apenas 352 (48\%) correspondiam ao endereço posto no Cadastro. (BRASIL, 2006n, p. 10-11) Esse monitoramento estruturou-se sobre quatro questionamentos, fundamentados nas recomendações e determinações do TCU para a correção das deficiências do Cadastro quando da auditoria de 2002:

a. "A base de dados do Cadastro Único encontra-se adequadamente atualizada?";

b. "O critério de unicidade do Número de Identificação Social - NIS está sendo observado na base do Cadastro Único?”; 
c. "Os municípios estão sendo devidamente apoiados pelo Ministério do Desenvolvimento Social e Combate à Fome - MDS e CAIXA para trabalharem com o Cadastro?” e;

d. "Existem procedimentos para identificar subdeclaração de renda?”. (BRASIL, 2006n, p. 9-10) Além disso, verificou-se o cumprimento da recomendação de se criarem indicadores de desempenho sobre a operação do Cadastro.

Verificando o estágio de atualização do CadÚnico, o TCU apresenta o que seriam os dados constantes de sua base em agosto de 2005: 10,9 milhões de famílias, perfazendo 43,5 milhões de pessoas, destacando que, com a posterior campanha de recadastramento "Bolsa Família Chama", promovida pelo MDS a partir de novembro de 2005, pretendia-se alcançar 11,2 milhões de famílias, ou 47,2 milhões de pessoas. (BRASIL, 2006n) Parte dessa informação parece estar equivocada ou confunde dados entre o Bolsa Família e o CadÚnico, pois 11,2 milhões de famílias foi a meta estabelecida para cobertura do Programa em 2006, e a campanha referida foi direcionada especificamente às famílias beneficiárias ou elegíveis para o mesmo ("Bolsa Família Chama”), uma medida complementar às ações de atualização do Cadastro, adotadas desde o início de 2005, envolvendo especialmente os municípios, executores do CadÚnico. Mas esse equívoco se corrige ao tratar da "estratégia de atualização dos dados", cujo balanço apresentado para dezembro de 2005 foi de $37,2 \%$ de cadastros atualizados (BRASIL, 2006n), e os dados de julho de 2006 identificam 15.334.771 famílias cadastradas, das quais 11.135.523 inclusas no SIBEC (BRASIL, 2006n), ou seja, 72,6\% dos cadastros referiam-se a famílias beneficiárias dos programas de transferência de renda e, em números absolutos, aproximava-se da meta estabelecida para o ano. O TCU atribui esses resultados à campanha de recadastramento e à criação do IGD para incentivo aos municípios, com definição de critérios e prazo para atualização de dados (BRASIL, 2006n); medidas que corresponderiam a recomendações feitas pelo Tribunal após a auditoria de 2002. Nesse bojo, entra também a possibilidade de os municípios realizarem alterações diretamente no cadastro, funcionalidade que, segundo o TCU, foi implementada desde a versão 5.0 do software de entrada de dados e que foi mantida na versão 6.o.2, de maio de 2006, com um avanço relevante: a abertura para a gestão direta de benefícios, realizada através do SIBEC. 
De acordo com o relatório de monitoramento do TCU, apesar da implementação das recomendações para atualização cadastral, a aplicação do "roteiro de verificação de informações" às famílias entrevistadas acabou mostrando a persistência de divergências significativas entre os dados cadastrados e os verificados em campo. Esta verificação considerou principalmente as seguintes variáveis: as "características domiciliares" $(62,5 \%)$, as "despesas" (6o\%), a "composição familiar" (42,6\%) e a "renda" (>40\%), seguidos dos dados referentes à identificação dos beneficiários (Nome, CPF, NIS) e outros. (BRASIL, 2006n)

Embora o TCU não apresente uma análise aprofundada sobre esse aspecto, percebe-se que as famílias entrevistadas acumulam mais de um tipo de divergência, o que pode ter implicação direta tanto sobre a composição dos benefícios concedidos, quanto sobre a delimitação do público-alvo do PBF ("pobre" e "extremamente pobre"), segundo as variáveis estabelecidas. De todo modo, embora importe, como um sinalizador, o quantitativo de famílias entrevistadas (352), é insignificante para a avaliação das condições do conjunto de dados do Cadastro (o,0023\%), além do que, o relatório não informa se essas famílias são ou não beneficiárias do Bolsa Família, o que daria a dimensão do peso que esses dados têm (Figura 2).

Figura 2 - Divergências entre observações de campo e os registros do Cadúnico, para 352 famílias, segundo o TCU $-2006(\%)^{70}$

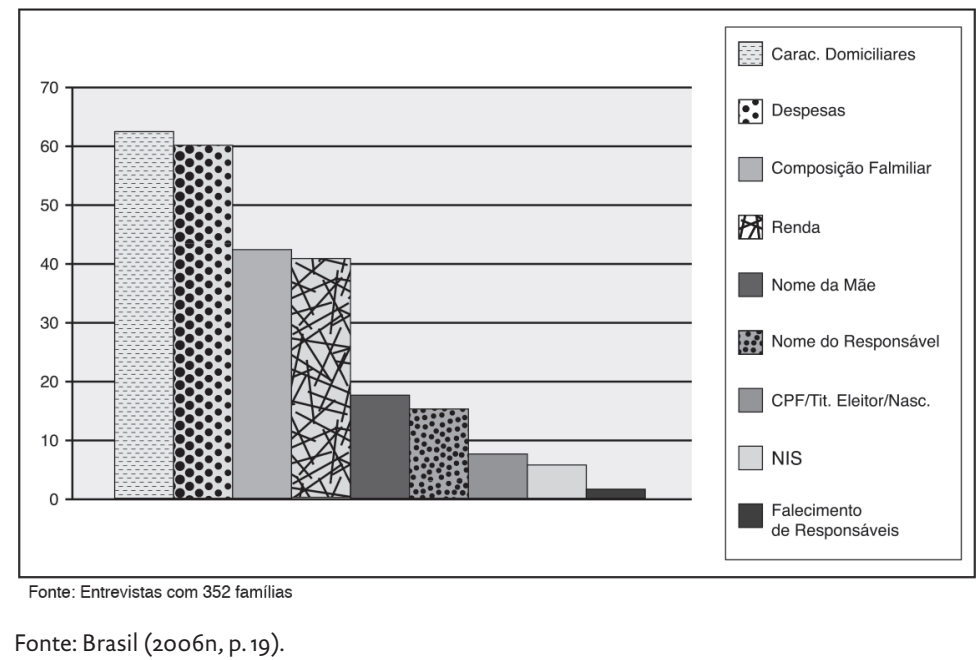

$70 \quad$ Título original: porcentagem de famílias entrevistadas que apresentaram divergências de dados em relação ao Cadúnico. 
O relatório atribui essas divergências ao processo de coleta de dados, atentando para a falta de supervisão do trabalho de campo, o que permitiria ter controle sobre a qualidade das informações, a exemplo do que se faz nas pesquisas do IBGE, onde se refazem cerca de $20 \%$ das entrevistas para confirmação dos dados. (BRASIL, 2006n) Nesse mesmo sentido, apresenta-se a necessidade de cruzamento dos dados com outras bases, como o SISOBI. Segundo o TCU, o MDS havia informado que não era possível o cruzamento entre essas duas bases pela falta de "uma chave primária comum" entre elas; a despeito disso, os técnicos do Tribunal fizeram esse cruzamento utilizando-se de um software específico (“ACL”ㄱ), comparando os números de CPF, o que resultou na identificação de 775 casos coincidentes, apenas no Rio Grande do Norte (BRASIL, 2006n), pelo que o Tribunal reitera a determinação de que a SENARC proceda a esse cruzamento.

Quanto à questão que trata da "unicidade do NIS", o TCU destacou que, embora a CEF tivesse adotado procedimentos de correção de multiplicidades de NIS, elas ainda ocorriam. Em verificação realizada sobre os dados do CadÚnico para o Rio Grande do Norte, a partir do cruzamento dos dados de identificação dos beneficiários, localizaram-se 1.765 casos de multiplicidade de NIS, mais de $1 / 3$ do que fora verificado quando da auditoria, em 2002 (Tabela 1). O Tribunal realizou ainda outros cruzamentos e obteve novas ocorrências de duplicidades. Em vista disso, o TCU determinou à SENARC o cancelamento dos benefícios pagos irregularmente, e à Caixa Econômica, o aperfeiçoamento do módulo de auditoria do Cadúnico para barrar as multiplicidades. (BRASIL, 2006n) É importante observar que os cruzamentos realizados pelo TCU incluíram quase que unanimemente o $\mathrm{CPF}$, identificando registros em que este campo do relatório coincidia, ou seja, o elemento inserido como principal critério de validação dos cadastros também apresenta fragilidades, provavelmente decorrentes de falhas nos mecanismos de crítica dos dados inseridos, em outras palavras, falhas no software de entrada e manutenção de dados.

$71 \quad$ O documento do TCU não descreve o significado da sigla ACL. Pesquisa em outras fontes demonstraram que se trata do Audit Command Language, um software que permite o cruzamento de dados em formatos distintos. 
Tabela 1 - Multiplicidade de NIS entre beneficiários do PBF - RN, Setembro de 2002 e junho de 2006 , segundo TCU ${ }^{72}$

\begin{tabular}{|c|c|c|c|c|}
\hline Critério & $\begin{array}{l}\text { № Pessoas } \\
2002\end{array}$ & $\begin{array}{l}\text { NIS } \\
\text { Excedentes } \\
2002\end{array}$ & $\begin{array}{l}\text { № Pessoas } \\
\quad 2006\end{array}$ & $\begin{array}{l}\text { NIS } \\
\text { Excedentes } \\
2006\end{array}$ \\
\hline $\begin{array}{l}\text { (A) CPF + Nome + Data } \\
\text { de Nascimento + Nome } \\
\text { da Mãe }\end{array}$ & 4 & 4 & 45 & 45 \\
\hline $\begin{array}{l}\text { (B) } \mathrm{CPF}+\text { Nome + Data de } \\
\text { Nascimento }\end{array}$ & 1 & 1 & 18 & 18 \\
\hline $\begin{array}{l}\text { (C) } \mathrm{CPF}+\text { Nome + Nome } \\
\text { da Mãe }\end{array}$ & 458 & 461 & 207 & 207 \\
\hline (D) $\mathrm{CPF}+$ Nome & 220 & 220 & 138 & 138 \\
\hline $\begin{array}{l}\text { (E) CPF + Data de } \\
\text { Nascimento + Nome da } \\
\text { Mãe }\end{array}$ & 782 & 783 & 324 & 324 \\
\hline (F) CPF + Nome da Mãe & 100 & 100 & 315 & 315 \\
\hline $\begin{array}{l}\text { (G) } \mathrm{CPF}+\text { Data de } \\
\text { Nascimento }\end{array}$ & 298 & 298 & 13 & 13 \\
\hline (H) CPF & 1.165 & 1.181 & 612 & 612 \\
\hline $\begin{array}{l}\text { (I) Nome + Data de } \\
\text { Nascimento + Nome da } \\
\text { Mãe }\end{array}$ & 1.841 & 1.844 & 93 & 93 \\
\hline Total & 4.869 & 4.892 & 1.765 & 1.765 \\
\hline
\end{tabular}

Fonte: Brasil (2006n, p. 26).

Em relação ao apoio dado pela Caixa Econômica e pelo MDS aos municípios na utilização do CadÚnico, considerando os serviços prestados para orientação e esclarecimento de dúvidas, a maioria dos gestores entrevistados avaliou que ainda não atendiam satisfatoriamente às suas necessidades, apresentando dificuldades de comunicação e, em determinados casos, com prestação de informações incorretas (BRASIL, 2006n); contudo, verificou-se que houve avanço na criação e aperfeiçoamento de canais de comunicação, a exemplo do Informe Bolsa Família, em 2005. Destaca-se também a realização de atividades de capacitação para a operação do software do CadÚnico e do SIBEC, que teriam atingido 4.30o municípios, de

72 Título original: “Número de registros com duplicidade de NIS, segundo critérios de identificação, no cadastro de famílias beneficiárias do Programa Bolsa Família no Estado do Rio Grande do Norte em setembro de 2002 e junho de 2006 ". 
todos os estados, e foram avaliadas positivamente pelos gestores municipais, mas tidas como insuficientes em virtude da baixa carga horária. Além disso, a SENARC sinalizara com a perspectiva de implantar a capacitação por demanda municipal e a "implantação de cursos de educação à distância" (BRASIL, 2006n, p. 33) a partir do mês de outubro 2006. O problema principal apontado em relação ao apoio aos municípios foi a dificuldade na troca de informações com a Caixa Econômica, mais especificamente, em razão do elevado número de rejeições geradas pelo sistema central, pois isso incorreu em atrasos na validação dos registros e, consequentemente, no repasse de recursos aos municípios, os quais já haviam assumido passivos financeiros para a realização do cadastramento, amparados nos recursos a receber.

Quanto à última questão posta pelo monitoramento do TCU, relativa aos "procedimentos de crítica da renda declarada", o relatório informou que o MDS cruzou os dados do CadÚnico com a RAIS (MTE), estando pendente o mesmo procedimento para o SISBEN (INSS), como fora recomendado após a auditoria (2002). O cruzamento com a RAIS permitiu o cancelamento de mais de 80 mil benefícios, até então pagos indevidamente, representando uma economia estimada em $\mathrm{R} \$ 59$, 3 milhões por ano. (BRASIL, 2006n) O TCU estima que esses números devem aumentar após comparados com dados do SISBEN, pois num cruzamento realizado pelo Tribunal, apenas para o Rio Grande do Norte, constatou-se indícios de subdeclaração em 3,6\% dos cadastros. Em vista disso, o TCU determina que o MDS proceda a esse cruzamento e que mantenha frequência anual em relação à RAIS (BRASIL, 2006n)

Além de apurar essas questões (atualização cadastral, unicidade do NIS, apoio aos municípios e criticidade da renda declarada), o TCU avaliou o cumprimento das recomendações de se instituírem indicadores de desempenho para o Cadastro, especialmente taxa de famílias cadastradas pertencentes ao público-alvo, taxa de cadastros rejeitados, taxa de NIS duplicados, taxa de atingimento da meta municipal de cadastramento e grau de convergência da renda per capita média no CadÚnico em relação ao Censo 200o. O Tribunal considerou essa recomendação parcialmente cumprida, sugerindo ajustes em alguns casos. Curiosamente, o relatório não faz menção nesse tópico ao IGD, possivelmente porque já o tratou na análise dos incentivos aos municípios. Há que se considerar, porém, que a finalidade do Índice é justamente avaliar o desempenho dos municípios na gestão do CadÚnico e do PBF, sendo a remuneração uma consequência disso, tanto 
que metade do peso na sua composição é dado ao "ICadÚnico", resultante do número de cadastros atualizados sobre os cadastros válido. (BRASIL, 2006c) Seguramente, as recomendações do TCU tiveram influência sobre a criação desse índice. Ao final desse monitoramento, o TCU considerou que $68,18 \%$ das recomendações que fizera a partir da auditoria sobre o Cadastro Único (2002) foram implementados (BRASIL, 2006n, p. 45), o que teria contribuído para uma economia mensal de 21,6 milhões de reais aos cofres públicos, destacadamente pelas medidas de correção das multiplicidades de NIS. (BRASIL, 2006n)

Esse relatório de monitoramento do TCU reivindica para si o mérito pelo aperfeiçoamento do Cadúnico, o que dificilmente pode ser contestado, considerando a proximidade entre as medidas adotadas pelo MDS e as recomendações e determinações formuladas pelo Tribunal. Mas a equipe técnica do Ministério apresentará a sua própria avaliação sobre esse "processo de qualificação do Cadastro Único”, ocorrido entre os anos de 2005 e 2006, conforme relatório elaborado pela SENARC com a síntese de todo esse processo. (PROCESSOS..., 2007)

Segundo esse relatório, até o início de 2005, o MDS não tinha acesso direto ao Cadastro, pois a base de dados era operada exclusivamente pela Caixa Econômica, o agente operador do Bolsa Família (PROCESSOS..., 2007), o que significa dizer que, de fato, a gestão do programa e, consequentemente, o processo de seleção de beneficiários não estava sob o controle do Governo. Por outro lado, a verificação de inconsistências demandava acesso integral aos dados, e essa situação forçou o MDS a "internalizar” o Cadastro; não a base principal, mas uma cópia, suficiente para a elaboração de um diagnóstico sobre a condição em que se encontrava o Cadúnico. De posse dos dados, a equipe do MDS estabeleceu algumas "categorias de verificações” para a realização do pretendido diagnóstico:

i) cruzamento entre variáveis; ii) documentação inexistente com o objetivo de identificar pessoas sem nenhum documento; iii) documentos incompletos; iv) renda para identificar inconsistências entre as informações referentes à situação no mercado de trabalho e à renda/remuneração declarada, tais como indicação de vínculo empregatício sem renda declarada etc.; v) responsável legal para identificar pessoas menores de 16 anos com indicação de responsável legal; vi) idade versus situação no mercado de trabalho; vii) renda versus despesas para identificar situações, nas quais a despesa é superior em $25 \%$ à renda declarada; viii) grau de instrução e a série escolar. (PROCESSOS..., 2007, p. 55) 
Pode-se observar que a preocupação principal desses diversos aspectos levantados não foi identificar as multiplicidades de registros (NIS), como se deu em alguns momentos anteriores, mas verificar se há correspondência entre as informações aferidas e os requisitos de elegibilidade do PBF. Isso é bastante claro, por exemplo, quando se busca comparar a despesa familiar com a renda declarada, ou ainda quando se lança mão da comparação dessa renda com os dados da RAIS (MTE). Em outras palavras, o objetivo do MDS em depurar o Cadastro seria expurgar os registros dos não pobres e garantir uma focalização mais precisa para o Bolsa Família, uma vez que era considerado o "programa estruturante do Cadastro Único". (PROCESSOS..., 2007, p. 54)

Com base nos resultados, o MDS concluiu que, de uma forma gera,1 os dados tinham pouca qualidade e estavam desatualizados, mas que ainda assim havia pouco mais de $30 \%$ de registros considerados válidos, o que afastou a alternativa de descarte integral do Cadastro. Essa "validação", que antes se referenciava no aval das instâncias de controle social (CGL, por exemplo), agora vai ganhar um novo significado, dado pelo cumprimento de requisitos formais, verificados de forma estritamente eletrônica:

Estabeleceu-se, assim, o conceito de cadastro válido como sendo aquele que, além de apresentar todos os campos obrigatórios preenchidos, para todos os membros da família, deveria apresentar o registro, ao menos para o responsável legal, de um documento de emissão controlada nacionalmente, CPF ou título de eleitor. (PROCESSOS..., 2007, p. 56)

A instituição de "critérios de validação" para o CadÚnico se deu em maio de 2005, através da IO n. ${ }^{\circ} 7 / 2005$, como se viu acima, e mostrou-se uma medida importante, pois, ao se separar os cadastros válidos, eliminavam-se já as multiplicidades geradas pela apresentação de diferentes documentos de identificação por um mesmo beneficiário a diferentes cadastradores; decerto, não é uma solução definitiva para esse problema, porque outros fatores contribuem para a replicação do NIS, como a digitação incorreta de nomes, por exemplo, mas já oferece uma alteração significativa.

O diagnóstico do MDS identificou, dentre os principais fatores geradores de inconsistências, o próprio software desenvolvido pela Caixa Econômica para entrada e manutenção dos dados. "O desenho desse aplicativo, além de tecnologicamente defasado, não incorporava a funcionalidade de checagem de informações inconsistentes antes da inclusão na base de da- 
dos local”. (PROCESSOS..., 2007, p. 52) Note-se que essa era a versão 5.0 do software, cujo primeiro monitoramento do TCU (2004) apontou como uma das soluções apresentadas pela Caixa Econômica para atualização de dados e superação de incompatibilidades. A constatação do MDS revela que essa era ainda uma ferramenta muito frágil e incompleta para servir à alimentação do banco de dados do Cadastro.

A equipe do MDS constatou a falta de clareza nas regras e procedimentos a serem seguidos na operação do Cadúnico, o que dificultava a compreensão por parte dos gestores municipais que não consideravam o cadastramento e a atualização de dados como um processo permanente. Isso demonstra que os procedimentos adotados anteriormente pelo Ministério, a exemplo do previsto no Decreto 5.209/2004, não se efetivaram, ou talvez não existissem ainda as condições para que se efetivassem. Além disso, verificou-se também que os municípios não tinham recursos suficientes humanos e tecnológicos - para essa operação contínua do Cadastro, o que se corrigirá gradualmente, como já fora analisado.

O êxito das ações realizadas pelo Ministério para a qualificação dos dados do CadÚnico, deve-se certamente ao fato de, pela primeira vez, esse Cadastro ter sido tratado efetivamente como um instrumento de política pública, sendo o alvo principal da intervenção institucional, com ações articuladas e a construção de uma estrutura institucional de gestão. $\mathrm{O}$ mais importante é que as ações de aprimoramento não se deram isoladas, apenas na esfera nacional, embora aí se operasse a definição de regras, mas foi necessariamente o comprometimento dos municípios com a execução do Cadastro que permitiu a sua "qualificação". O relatório do MDS informa que desde o início "os 5.561 municípios receberam um CD-ROM com os resultados para apoiá-los na quantificação e na identificação das inconsistências de seus respectivos cadastros, orientando-os quanto à atualização cadastral". (PROCESSOS..., 2007, p. 55) Não se trata mais de passar aos municípios uma listagem simplificada de informações sobre os beneficiários locais, mas de inseri-los na dinâmica propriamente dita de qualificação do Cadastro. Isto se consolidou com a criação do instrumento de "adesão municipal” ao CadÚnico e ao PBF, quando a gestão compartilhada ganhou formalidade, institucionalidade. Em verdade, a adesão já era prevista desde a regulamentação do Bolsa Família (BRASIL, 2004a, Art. 11), mas não havia clareza sobre o instrumento para a sua operacionalização. Com a nova medida, as responsabilidades atribuídas ao município passaram a ser uma 
escolha do gestor local, que, para cumpri-las, contaria agora também com o apoio financeiro do Governo Federal. Esse apoio, por sua vez, será condicionado à validade dos cadastros realizados, considerando os critérios estabelecidos para esta validação.

Em outubro de 2006, período considerado pelo MDS como de finalização do processo de "qualificação" do Cadastro, avaliou-se que o número de cadastros válidos quase triplicou, passando dos 31,3\% iniciais para 92\%. Afirma-se que se excluiu cerca de 1,5 milhão de beneficiários que estavam fora do perfil dos programas, o que significou uma economia na ordem de 700 milhões de reais. Uma das conclusões dos técnicos do MDS foi de que esse resultado "trouxe credibilidade ao maior programa governamental de distribuição de renda do mundo". (PROCESSOS..., 2007, p. 59) Ainda dentre os resultados, verificou-se "a renovação do parque tecnológico em uso nos municípios”. (PROCESSOS..., 2007, p. 59) Esse, aliás, é um feito do CadÚnico que merece destaque, porque resolve ou reduz um dos principais gargalos de sua operação: a infraestrutura operacional, e com ela algumas dificuldades de comunicação que também retardavam o processo.

\section{O NIS DO CADÚNICO COMO ATESTADO DA CONDIÇÃO DE POBREZA PARA A CONCESSÃO DE BENEFÍCIOS ASSISTENCIAIS}

As ações realizadas durante os anos de 2005 e 2006 deram ao CadÚnico um novo significado. As mudanças operadas na base de dados permitiam fazer outros usos dela, para além da seleção de beneficiários para o PBF, com certa margem de segurança, no que tange aos fins da focalização de programas e benefícios sociais. Um exemplo claro disso pode ser observado na IO n. ${ }^{\circ} 16$, editada pela SENARC em janeiro de 2007 , que divulgou os "procedimentos operacionais para a concessão do desconto da tarifa social de energia elétrica”. (BRASIL, 2007c) A Tarifa Social é um benefício criado desde 2002, resultado da regulamentação ao disposto na Lei n.ำ 10.438/2002, de isenção, "ao consumidor integrante da Subclasse Residencial Baixa Renda [...] [que] tenha consumo mensal inferior a $80 \mathrm{kWh} / \mathrm{mês}$ ou cujo consumo situe-se entre 80 e $220 \mathrm{kWh} /$ mês" (BRASIL, 2002e, Art. $1^{\circ}$, § § $1^{\circ}$; - § $2^{\circ}$ ), do rateio dos custos de aquisição de energia elétrica. Trata-se, portanto, de um subsídio sobre a tarifa de energia elétrica para os consumidores de "baixa renda" situados numa faixa reduzida de consumo. De acordo com o 
Decreto n.. 4.336/2002, no Artigo 4º essa condição de "baixa renda" equivale ao que fora disposto anteriormente para o Auxílio Gás, ou seja, "unidades consumidoras" cuja renda per capta não ultrapasse I/2 salário mínimo e estejam registradas no CadÚnico. (BRASIL, 2002b, Art. $3^{\circ}$ )

Foi a Resolução Agência Nacional de Energia Elétrica (ANEEL) n. ${ }^{485}$, de 29 de agosto de 2002, que efetivamente regulamentou a "Tarifa Social de baixa renda”, pois nela foram sistematizados os critérios de elegibilidade para o benefício, ou seja, a classificação das famílias ou das "unidades consumidoras" na "Subclasse Residencial Baixa Renda”: possuir instalação elétrica por circuito monofásico (simples); ter consumo médio entre 80 e 220 kWh (calculado sobre um intervalo de 12 meses); ser cadastrado no Cadúnico ou ser beneficiário, efetivo ou potencial, dos programas Bolsa Escola ou Bolsa Alimentação e ter renda per capta mensal de até I/2 salário mínimo. (AGÊNCIA NACIONAL DE ENERGIA ELÉTRICA, 2002) Observe-se que esses critérios condicionam a execução da Tarifa Social à operação do CadÚnico e, consequentemente, às dificuldades daí decorrentes, o que dilatará diversas vezes o prazo para cumprimento dos critérios, como demonstra uma das considerações da justificativa apresentada à Resolução ANEEL no 308/2003, de 30 de junho de 2003, editada com esse fim: "o prazo [...] fixado pela Resolução 485/2002 [...] revelou-se insuficiente para a superação dos diversos problemas operacionais surgidos para o cadastramento nos programas sociais". (AGÊNCIA NACIONAL DE ENERGIA ELÉTRICA, 2003a)

Em 24 de dezembro de 2003, a Resolução ANEEL n.ำ 694 restringiu o público elegível à Tarifa Social às famílias elegíveis ao PBF, ou seja, cuja renda per capta se limitasse a $\mathrm{R} \$ 100$, oo mensais. Como era necessário comprovar inscrição no CadÚnico e, agora, habilitação ao Bolsa Família por parte das famílias pobres, os prazos para que isso se fizesse foram também, reiteradas vezes, prorrogados. É disso que trata a IO n.ำ16/2007; ela orienta à regularização do cadastro das famílias beneficiárias ou aptas ao benefício da Tarifa Social. O MDS identificou as famílias cuja renda declarada no CadÚnico divergia dos critérios do benefício e outras ainda não cadastradas e disponibilizou as informações aos gestores municipais para que se procedesse à atualização dos registros, após o que dever-se-ia gerar um "relatório analítico", através do aplicativo offline do Cadastro, para que os beneficiários apresentassem junto às concessionárias de energia elétrica, em 
substituição à autodeclaração que lhe dera acesso ao benefício ou para a concessão do mesmo, no caso das famílias ainda não beneficiadas.73

Há um detalhe que merece destaque nessa Instrução (n. ำ 16/2007): o tempo de trânsito de informações entre a Caixa Econômica e os municípios. Orienta-se ao gestor que, após a atualização dos dados no aplicativo de entrada e manutenção do Cadastro e sua respectiva transmissão à base central, ele "solicite ao responsável pela unidade domiciliar que retorne dentro de 2 semanas" (BRASIL, 2007c, p. 3) para ter acesso ao seu relatório, prazo estimado para o processamento dos dados e envio do arquivo-retorno. Isso demonstra que as dificuldades identificadas há cerca de um ano atrás, de falhas e retardo no processamento de dados (BRASIL, 2006h), causadas, dentre outros fatores, por limitações no software do CadÚnico, persistiam. Em consequência disso, foram mantidas as ações de aprimoramento do software offline. O Informe PBF n. ${ }^{\circ}$ 69, de 2 março 2007, apresenta uma nova versão do aplicativo, V.6.o.4, visando agilizar o processo de cadastramento e eliminar duplicidades. Um dos destaques é dado à geração do "relatório analítico de domicílios”, para a inscrição de beneficiários na tarifa social de energia elétrica. Quanto à multiplicidade dos dados, a novidade é que agora o aplicativo impede a duplicação de CPF e Título de Eleitor, um mecanismo que faz uma varredura da base de dados já no momento de sua instalação (atualização da versão anterior), corrigindo uma falha já identificada pelo TCU em seu último monitoramento (2006) e dando mais consistência à validação dos cadastros.

\section{O ALCANCE DE UM INSTRUMENTO PARA IDENTIFICAR E CARACTERIZAR SOCIOECONOMICAMENTE OS POBRES DO BRASIL}

Dando prosseguimento à rotina de verificação de consistência do CadÚnico, o MDS, em 2007, realizou uma nova auditoria sobre a base de dados central, cruzando suas informações de 2006 com as da RAIS do ano 2005. Os Informes PBF n. ${ }^{\circ} 77$ e 78 , de 28 de abril e 8 de maio de 2007 , respectivamente, trataram dessa auditoria, antecipando para os municípios as informações que lhes chegariam através da IO n. ${ }^{1}$ 18, de 15 maio 2007.

73 Não foram encontrados dados quantitativos específicos sobre a Tarifa Social, mas Mostafa e Silva (2007, p. 6) estimam cerca de 13 milhões de beneficiários inscritos para o ano de 2007. 
O Informe n. ${ }^{\circ} 78$ informou que houve mais de 500 mil registros com divergências de renda, sendo 198 mil colocados em averiguação e cerca de $330 \mathrm{mil}$ bloqueados. Considerando que os dados da RAIS podiam estar defasados, o MDS determinou que nenhum benefício fosse cancelado até que os municípios procedessem à revisão cadastral, com a respectiva repercussão sobre a folha de pagamentos do Bolsa Família. Embora a auditoria tenha identificado tantos indícios de inconsistência, esse não é o elemento mais importante na edição da IO n. $\stackrel{\circ}{18}$, afinal os resultados ratificam a importância desse procedimento na gestão do CadÚnico. A novidade está na redação formulada para essa Instrução, que apresenta o Cadúnico de uma forma mais consolidada, definindo claramente os objetivos do Governo em relação a ele.

O Cadastro Único de Programas Sociais do Governo Federal (CadÚnico) constitui-se na principal fonte de informações para a identificação e seleção de famílias e pessoas para ações de políticas públicas na área social. O Programa Bolsa Família (PBF) é o principal usuário das informações do CadÚnico, sendo também seu programa estruturante. Dessa forma, a boa qualidade das informações do CadÚnico assegura que as pessoas/famílias selecionadas para as ações sejam de fato aquelas que atendem aos critérios de elegibilidade de tais políticas. Em suma, a boa qualidade das informações cadastrais garante um maior nível de focalização e eficácia das políticas sociais. (BRASIL, 2007d, p. 1, grifo nosso)

O trecho destacado permite remontar ao discurso uníssono do Governo Federal nos seus primeiros meses de gestão (2003), notadamente às proposições do Ministério da Fazenda com respeito às políticas sociais, às quais se atribuía falta de efetividade e distorções na focalização. Não se trata da repetição do prólogo, mas da realização do último ato. Não era outra a perspectiva do então Secretário-Executivo do MAS, Ricardo Henriques, em seu discurso no CNAS em setembro de 2003: "transformaremos esse cadastro num instrumento sólido não só para o Programa de Transferência de Renda, mas para o planejamento da política social” (BRASIL, 20031, p. 203), afirmou ele. Dito e feito! O CadÚnico desenvolve-se numa perspectiva ascendente de depuração de dados dos considerados não pobres, com vistas a fornecer ao Bolsa Família e a outros programas o dado puro dos efetivamente "mais pobres entre os pobres". Mas quem são os atores dessa ação de transformar, indicada na fala de Henriques?

Desde aquela época, os conselheiros da Assistência Social reclamavam o reconhecimento da importância dos municípios no processo de 
cadastramento e na operação dos programas sociais, ao tempo em que questionavam os critérios utilizados para a definição do conceito de pobreza. A Instrução n.. 18/2007 parece responder sumariamente às duas coisas: “as informações de renda representam o principal fator na seleção das famílias" e por isso "merecem uma atenção especial por parte dos 'gestores locais' e do [MDS]”. (BRASIL, 2007d, p. 1, grifo nosso) A auditoria do MDS teria mesmo a finalidade de "apoiar o trabalho dos municípios" para a "regularização da situação dessas famílias”. (BRASIL, 2007d, p. 2)

E o que se anunciou na IO n. ${ }^{\circ} 18 / 2007$ foi ratificado no Decreto $n^{\circ} 6.135$, de 26 de junho de 2007, o qual revogou os decretos anteriores que regiam o CadÚnico e estabeleceu novos contornos para o mesmo. Quando do Decreto . $^{3}$ 3.877/2001, instituiu-se um formulário de coleta de dados como "instrumento de Cadastramento Único” (BRASIL, 2001e, Art. $1^{\circ}$ ); no novo documento, porém (Decreto n.․ 6.135/2007), apresenta-se o Cadastro como sendo "constituído por sua base de dados, instrumentos, procedimentos e sistemas eletrônicos”. (BRASIL, 2007a, Art. 2ํㅗㅇ § $3^{\circ}$ ) De uma forma geral, esse Decreto dá nova qualificação ao agora formalmente chamado CadÚnico, o que faz com que a seleção de beneficiários, por exemplo, não seja mais a única ou mesmo a principal função que o Cadastro preenche.

O Cadastro Único para Programas Sociais - CadÚnico é instrumento de identificação e caracterização sócio-econômica das famílias brasileiras de baixa renda, a ser obrigatoriamente utilizado para seleção de beneficiários e integração de programas sociais do Governo Federal voltados ao atendimento desse público. (BRASIL, 2007a, Art. $2^{\text {o}}$ )

Há uma mudança conceitual evidente e significativa. O Cadastro pretende agora tanto a "identificação" quanto a "caracterização socioeconômica” das famílias de baixa renda, para além dos beneficiários dos PTRs. Incorpora-se, portanto, um componente censitário em seu conteúdo. Com base nessa fonte é que se opera a seleção de beneficiários, não apenas dos PTR, mas dos "programas sociais" de forma ampla, e em seguida se viabiliza o objetivo de integração desses programas, já previsto anteriormente (Decreto $n$. . $3.877 / 2001$ ), através da identificação dos beneficiários, referenciado pelo NIS atribuído aos indivíduos cadastrados.

À semelhança do decreto anterior (3.877/2001), no novo documento (Decreto n.․ 6.135/2007), os programas previdenciários são isentados da 
obrigatoriedade de uso do Cadastro (BRASIL, 2007a, Art. 2ํㅡ, § \ $1^{\circ}$ ), e o BPC74 é trazido à baila, deixando-lhe facultativo o uso do CadÚnico. (BRASIL, 2007a, Art. $2^{\circ}, \S_{2^{\circ}}$ ) Os objetivos de unicidade das informações, de integração dos programas e "políticas" e de racionalização do cadastramento, como anteriormente, devem se dar no processamento dos dados, através da atribuição do NIS. Esse é um dado essencialmente importante, porque sugere que é através desse código que o CadÚnico se operacionaliza. Uma novidade é que o processamento acontecerá "na base nacional do CadÚnico" e a atribuição do NIS deve ser feita "pelo órgão gestor nacional" do Cadastro (BRASIL, 2007a, Art. $3^{\text {o. }}$ - Art. $5^{\circ}$ ), ou seja, a responsabilidade formal pelo processamento dos dados está com o MDS, embora nunca tenha saído do controle da CEF.

Outro dado importante do novo Decreto é a redefinição conceitual das variáveis básicas adotadas na composição dos critérios de identificação de sua população alvo: família, domicílio e renda.

I - família: a unidade nuclear composta por um ou mais indivíduos, eventualmente ampliada por outros indivíduos que contribuam para o rendimento ou tenham suas despesas atendidas por aquela unidade familiar, todos moradores em um mesmo domicílio.

II - família de baixa renda: sem prejuízo do disposto no inciso I:

a) aquela com renda familiar mensal per capita de até meio salário mínimo; ou

b) a que possua renda familiar mensal de até três salários mínimos;

III - domicílio: o local que serve de moradia à família;

IV - renda familiar mensal: a soma dos rendimentos brutos auferidos por todos os membros da família [...]

V - renda familiar per capita: razão entre a renda familiar mensal e o total de indivíduos na família. (BRASIL, 2007a, Art. $4^{\circ}$, grifo do autor)

Esse dado comporta dois aspectos que merecem destaque. Um deles é que essa definição será importante para as equipes de cadastramento, no

74 O BPC foi instituído pela Lei n. ${ }^{\circ} 8.742 / 1993$, LOAS (Art. 20), regulamentando o previsto na Constituição Federal de 1998, em seu Art. 203, inciso V, para garantia de "um salário mínimo de benefício mensal à pessoa [deficiente] e ao idoso que comprovem não possuir meios de prover a própria manutenção ou de tê-la provida por sua família”. 
momento de registro dos dados no formulário. Por outro lado, é um dado que distingue essencialmente a legislação do Cadastro daquela dos programas a que serve, como o Bolsa Família, reiterando seus objetivos mais amplos. Tanto assim que o público do Cadúnico é formado por famílias com renda per capta de até $\mathrm{I} / 2$ salário mínimo ou mesmo renda total de até três salários mínimos, independente da composição familiar, e excepcionalmente a renda da família pode ainda ser superior ao estipulado, caso atenda a requisitos de programas sociais específicos. (BRASIL, 2007a, Art. 6으, § $1^{\circ}$ ) Confirmando a ampliação do escopo do CadÚnico, o Informe PBF n.․9, de 3 de outubro de 2007, afirmou que "essa mudança foi feita com o objetivo de possibilitar que o Cadastro seja utilizado por políticas públicas que utilizam o critério de renda acima daquele tradicionalmente utilizado pelo Cadastro Único". (BRASIL, 2007j)

Quanto às competências, é o MDS que aparece, como já se viu, como responsável pela gestão nacional do cadastro, pela expedição de normas, "por coordenar, acompanhar e supervisionar a implantação e a execução do CadÚnico" e estimular o uso do Cadastro nas distintas instâncias federais, nos estados, Distrito Federal e municípios. (BRASIL, 2007a, Art. $5^{\circ}$ ) A responsabilidade pelo cadastramento está claramente atribuída aos municípios, condicionados à adesão prévia e sob critérios operacionais que vão além do preenchimento dos formulários, como a necessidade de vincular a família ao domicílio e a um "responsável pela unidade domiciliar”, preferencialmente mulher e a partir dos 16 anos de idade. (BRASIL, 2007a, Art. $\left.6^{\circ}\right)$ Esse é o momento em que retornarão as variáveis definidas anteriormente (família, baixa renda etc.) na forma de indicadores a serem observados durante o cadastramento.

Definiu-se também, nesse Decreto, um prazo máximo de validade dos dados do Cadastro (BRASIL, 2007a, Art. $7^{\circ}$ ), o que impôs à sua manutenção uma rotina de atualizações, além da adoção de "medidas periódicas para a verificação permanente da consistência das informações cadastrais" (BRASIL, 2007a, Art. 9º), mecanismo que atuaria na correção ou redução de dificuldades geradas sob a vigência da norma anterior. Conquistada maior confiabilidade dos dados, o seu uso passa a servir à "I - formulação e gestão de políticas públicas; e II - realização de estudos e pesquisas”. (BRASIL, 2007a, Art. 8)

Um dado contraditório no novo Decreto, porém, é que, embora se pretenda censitário para a população de "baixa renda", limita quantitati- 
vamente as famílias a serem cadastradas ao estabelecer como parâmetro as "estimativas do número de famílias" nessa condição, disponibilizadas pelo MDS. (BRASIL, 2007a, Art. 11) Além disso, no que diz respeito às despesas com o processamento dos dados, há dependência da alocação orçamentária desse Ministério, o que pode também influenciar na pretensão de censo.

De todo modo, o Decreto n.ำ.135/2007 faz uma síntese das ações desenvolvidas pelo MDS entre os anos 2005 e 2006 para a qualificação do CadÚnico, confirma a unicidade cadastral e consolida um conjunto de regras para operação e monitoramento desse cadastro; é como se instituísse um novo CadÚnico. Daí em diante, as atividades de verificação e atualização do Cadastro serão uma constante, e as ações de alteração do software off-line, bem como de capacitação de gestores e operadores, terão por finalidade o aprimoramento da estrutura já estabelecida, o que permitirá uma contínua diversificação de usos dos dados do Cadastro.

Assim, o Informe PBF n. ํㅜㄴ 104, de 21 de novembro de 2007, anunciará a iminente disponibilização de uma nova versão do software de entrada de dados, v. 6.o.5, a partir da qual “o Cadastro Único estará mais qualificado como fonte de informação para a gestão de políticas, tanto do Governo Federal como dos estados e municípios”. (BRASIL, 2007k) O novo aplicativo trará recursos adicionais de controle e segurança dos dados, além da inserção de novos campos para "identificação da pessoa" e "identificação do domicílio", alteração feita exclusivamente no software, pelo que se sugeriu que os municípios adotassem estratégias para registro das novas informações no formulário de coleta de dados. Dentre os novos campos, inseriu-se a variável "liberto de trabalho escravo", resultado de parceria firmada entre o MDS e o MTE para "desenvolver ações que possibilitem a reinserção social dos cidadãos libertados de situação análoga à escravidão”. (BRASIL, 2007l) À época, o MTE identificou 6.353 pessoas em situação de trabalho escravo, distribuídas em cerca de $20 \%$ dos municípios brasileiros. Essas informações seriam passadas ao MDS para que este Ministério providenciasse junto aos municípios o cadastramento das pessoas e sua respectiva inclusão no Bolsa Família, quando coubesse. Embora possa ser interpretada como sendo de caráter residual, essa condição de "escravidão" atribuída a determinadas formas de exploração do trabalho no Brasil atual tem uma simbologia singular na compreensão do que se considera a condição de pobreza, porque a "reinserção social" que se pretende é o reconhecimento social dessa condi- 
ção, a disposição dos indivíduos sob o "foco" do Estado. O trabalho escravo passa a ser mais uma situação definidora de atributos da pobreza.

Outro campo importante inserido no novo software, na seção de identificação da pessoa, foi o de "programas habitacionais", atendendo a uma definição do Ministério das Cidades de "que as famílias a serem beneficiadas pelos programas habitacionais sejam obrigatoriamente incluídas no Cadastro Único". (BRASIL, 2007e) Confirma-se com isso, a definição do CadÚnico como fonte centralizada de informações da população alvo de políticas e programas sociais. Mas não apenas isso. Há um caminho de volta: toda ação do Estado direcionada à área social condiciona-se às informações do CadÚnico; fora dessa base de dados, não existem pobres aos olhos do Estado. Nisso está a importância das campanhas promovidas pelo Governo Federal para combater o sub-registro de nascimento. Ao final de 2007, o MDS, em parceria com a Secretaria de Direitos Humanos (SEDH), lançou a cartilha "Registro Civil de Nascimento", direcionada aos gestores municipais do Bolsa Família, orientando-os à mobilização dos diversos atores sociais em favor do registro de nascimento (BRASIL, 2007l), tendo como uma das estratégias sugeridas para a identificação de pessoas sem documentação o processo de cadastramento do CadÚnico. Essa campanha se repetirá ao final de 2008 de forma mais ampla e assumindo caráter permanente. (BRASIL, 2008e)

O apoio financeiro concedido aos municípios se tornou também permanente em 2008, através da Portaria n. 66/2008, de 3 de março 2008, que alterou o texto da Portaria $\mathrm{n}^{\mathrm{o}}$ 148/2006 com este fim, ${ }^{75}$ estabelecendo critérios mais rígidos para a transferência dos recursos, a partir da definição de uma pontuação mínima para o cálculo do IGD $(0,5)$, o que impôs aos municípios maior exigência na execução e acompanhamento do CadÚnico e do Bolsa Família. Para isso, o próprio software do Cadastro oferecia ferramentas importantes, representadas pelos relatórios que podem ser gerados com este aplicativo, que, devido ao grau de consistência adquirido, passam a ser um instrumento para formulação de políticas públicas. O Informe PBF n. ${ }^{\circ}$ 121, de 4 de abril de 2008, leva essas informações aos municípios, indicando as possibilidades de usos desses relatórios e os procedimentos para acessá-los através do aplicativo offline. (BRASIL, 2008d)

75 A instituição do apoio financeiro aos municípios na forma do IGD foi consolidada através da Lei n. ${ }^{\circ} 12.058$, de 13 de outubro de 2009. 
O Relatório Sintético apresenta o número de domicílios, famílias e pessoas cadastradas e é importante para o município conhecer as informações quantitativas da sua base. Com ele é possível verificar o número de pessoas com documentação e sem documentação e, dentro de cada grupo, os números por faixa etária, gênero, portadores de necessidades especiais e pessoas que estão definidas como responsáveis pelas unidades familiares. Este relatório também permite verificar quais cadastros estão ativos e inativos no município. (BRASIL, 2008d, grifo do autor )

Esse conjunto de informações é apresentado em formatação predefinida, mas pode ser manipulado de acordo com o interesse de quem o utiliza, permitindo o cruzamento de variáveis específicas, com resultado disposto num "relatório analítico". Esse estágio ao qual chegou o Cadúnico permite a utilização de suas informações para diversos fins, por qualquer das três esferas federativas, com relativa precisão na focalização do público -alvo das políticas sociais: a população de "baixa renda" e, mais especificamente, os "pobres" e "extremamente pobres". A exemplo disso, o Decreto n. ${ }^{0}$ 6.593/20o8, de 2 de outubro de 2008, regulamentou o Art. 11 da Lei n. ${ }^{0} 8.112 / 1990,{ }^{76}$ quanto à isenção de taxa de inscrição para realização de concurso público federal. Seriam isentos, a partir de então, os candidatos de "baixa renda" inscritos no Cadúnico, mediante requerimento declarando essa condição, como no caso da tarifa social de energia elétrica, confirmada pelo NIS atribuído pelo Cadastro.

Esse upgrade do CadÚnico exigiu do Governo Federal uma regulamentação específica para o Cadastro, o que se fez através da Portaria MDS n. ${ }^{\circ} 376$, editada em 16 de outubro de 2008 , ratificando os procedimentos de gestão do mesmo, com base na Lei e no Regulamento do Bolsa Família (Lei n. ${ }^{\circ}$ 10.836/2004 e Decreto n. ${ }^{\circ} 5 \cdot 209 / 2004$ respectivamente) e no Decreto n. ${ }^{\circ}$ 6.135/2007 que disciplina o próprio Cadastro. Em suma, fez-se uma compilação do que já se tinha publicado anteriormente em normas, instruções e comunicados em um único documento, com maior detalhamento de informações. É nesse momento, por exemplo, que o processo de cadastramento é classificado em fases: a) identificação do público-alvo; b)coleta de dados; c) inclusão dos dados no sistema e d) manutenção desses dados. (BRASIL, 2008c, Art. $3^{\circ}$ ) Para a coleta de dados, inseriu-se um elemento novo: quando a coleta não se desse através de visitas domicilia-

76 Trata-se do Regime Jurídico dos servidores públicos federais do Brasil. 
res, uma amostra de 20\% deveria ser selecionada para a visitação posterior, para confirmação das informações prestadas. (BRASIL, 2008c, Art. 10, $\S 2^{\circ}$ ) Esse tópico responde às observações feitas no último monitoramento do TCU (2006), de falta de checagem ao trabalho de campo para maior qualificação dos dados, como ocorria nas pesquisas do IBGE (BRASIL, 2006n, p. 20), e tem base, seguramente, na interação do MDS com esse Instituto para modificações no CadÚnico.

\section{O USO DAS INFORMAÇÕES CADASTRAIS NA PRODUÇÃO DE INDICADORES PARA DIMENSIONAR A CONDIÇÃO DE POBREZA}

A busca de consolidação do CadÚnico nos moldes já identificados desde a IO n⿳o 18 , de 15 maio de 2007, como "principal fonte de informações sobre a população de baixa renda", capaz de auxiliar os governos na formulação de políticas públicas, se confirma na instituição do Indice de Desemvolvimento Familiar (IDF) como ferramenta de acompanhamento das famílias constantes da base do CadÚnico. O Informe PBF nํㅗㄱ, 30 de dezembro de 2008, define esse Índice como "um indicador sintético que mede o grau de desenvolvimento das famílias, possibilitando apurar o grau de vulnerabilidade de cada família do CadÚnico". (BRASIL, 2008f)

Em verdade, a proposta original do IDF data do início da década de 200o, utilizando como fonte de dados a PNAD-IBGE, e alternativamente o CadÚnico, para avaliar as condições de pobreza no Brasil a partir do nível de desenvolvimento das famílias. Barros, Carvalho e Franco (2003), ao proporem o IDF, consideram que a pobreza é um fenômeno multidimensional, fato que oferece dificuldades para o seu tratamento conceitual, principalmente no que tange à sua "ordenação". Os autores afirmam que "Uma vez que só é possível obter ordenações completas entre escalares, caso se deseje ordenar a pobreza entre indivíduos ou entre sociedades, é necessário antes, que o conceito multidimensional de pobreza seja convertido num escalar". (BARROS; CARVALHO; FRANCO, 2003, p. 3) Tendo isso em conta, os autores consideram que o critério de "insuficiência de renda" mostra-se um indicador escalar eficiente, mas insuficiente para alcançar as várias dimensões da pobreza, o que torna necessária a criação de um índice escalar sintético, como o IDF, que é análogo ao IDH desenvolvido pelo Programa das Nações Unidas para o Desenvolvimento (PNUD), mas com a 
vantagem de poder ser aplicado tanto para a análise de unidades geográficas, como para grupos demográficos específicos.

O IDF é apresentado mesmo em contraposição ao IDH, em razão das limitações atribuídas a este, seja na definição de seus indicadores, nos quais o primeiro tem 48 contra apenas quatro do segundo, seja nos níveis de "desagregabilidade", que dão conta da "unidade mínima de análise para a qual se pode obter o índice sintético" (BARROS; CARVALHO; FRANCO, 2003, p. 6), na qual o IDF pode atingir não apenas unidades geográficas, mas famílias e grupos demográficos específicos, seja ainda em relação à "agregabilidade”, na qual, com o IDF, o índice de unidades de análise maiores pode ser obtido satisfatoriamente pela média daqueles calculados para unidades menores, pois "a população de referência para o cálculo de todos os indicadores é sempre a mesma: todas as famílias”. (BARROS; CARVALHO; FRANCO, 2003, p. 7)

O índice então proposto (IDF) se comporia por um conjunto de seis dimensões: "ausência de vulnerabilidade", para mensurar o acesso aos recursos necessários à satisfação das necessidades básicas familiares; "acesso ao conhecimento", para medir o grau de escolarização e qualificação profissional das famílias; "acesso ao trabalho", para medir disponibilidade, qualidade e remuneração do trabalho; "disponibilidade de recursos", para medir os níveis e a fonte de renda da família, diferenciando a renda gerada pela família daquela advinda de transferências do Estado; "desenvolvimento infantil”, para verificar situações de trabalho, o acesso à escola e mortalidade infantil; e "condições habitacionais", dando conta da situação do imóvel e infraestrutura disponível. Essas dimensões representam tanto os meios requeridos para a satisfação das necessidades das famílias quanto a satisfação efetiva dessas necessidades. (BARROS; CARVALHO; FRANCO, 2003) Elas são decompostas em 26 componentes, e estes, em 48 indicadores, cujo cálculo resultará num índice que varia entre zero e um, indicando piores ou melhores condições de vida, respectivamente.

Em junho de 2006, o MDS publicou uma versão preliminar de um manual com "orientações para o acompanhamento das famílias beneficiárias do Programa Bolsa Família no âmbito do Sistema Único de Assistência Social (SUAS)", no qual o CadÚnico já era apresentado como um "instrumento de conhecimento e avaliação das famílias", dado o seu objetivo de "identificar todas as famílias em situação de pobreza" do Brasil (BRASIL, 2006g, p. 21), aquelas com renda per capta de até meio salário mínimo, uma definição importante para a crítica da segmentação operada 
para fins de pagamento do benefício do Bolsa Família ("baixa renda, pobre" e "extremamente pobre"). Segundo o manual, os dados do CadÚnico proporcionam às três esferas governamentais "o diagnóstico socioeconômico das famílias cadastradas e a análise das suas maiores necessidades”, porque permitem saber "quem são, onde estão e como vivem as famílias em situação de pobreza no Brasil”. (BRASIL, 2006g, p. 22) O documento dá destaque à etapa de localização das famílias a serem cadastradas, considerando-a como "um processo de seleção prévia" no processo de cadastramento. (BRASIL, 2006g, p. 23)

Esse é um elemento especialmente relevante para a compreensão dos mecanismos utilizados para a construção da pobreza enquanto uma categoria social e das formas de intervenção da Administração Pública sobre ela. O IDF, resultante das informações constantes da base de dados do CadÚnico, é tomado como um diagnóstico da pobreza no Brasil. Funciona aí uma espécie de ciclo retroalimentador, porque a concepção do cadastro se pauta num conhecimento prévio do que é a pobreza, e as informações advindas dele é que propiciam o conhecimento sobre esse fenômeno. E é justamente à capacidade de gerar conhecimento do CadÚnico que o documento do MDS (2006) alude predominantemente: um instrumento que seria capaz de ultrapassar "as fronteiras do PBF, e mesmo da Assistência Social”, permitindo a "transferência de informações e comunicabilidade entre os diversos sistemas existentes”. (BRASIL, 2006g, p. 24) Um tipo de tecnologia capaz de identificar "o grau de vulnerabilidade, necessidades e potencialidades de uma família, de um grupo de famílias, ou até de uma comunidade” (BRASIL, 2006g, p. 24); nessa perspectiva, é apresentado o IDF, que aí, diferente da proposta original, aparece composto por cinco dimensões: "ausência de vulnerabilidade", "acesso ao conhecimento", "acesso ao trabalho”, “desenvolvimento infantil" e "condições habitacionais", excluiu-se, portanto, a variável "disponibilidade de recursos". O Índice seria calculado pelo MDS e disponibilizado aos gestores locais para a formulação de ações específicas.

Também em 2006, Barros, Carvalho e Franco publicaram um novo trabalho, Pobreza multidimensional no Brasil, onde o IDF foi apresentado nos mesmos moldes da proposta original, contemplando as seis dimensões e tendo por base os dados da PNAD-IBGE. Já em setembro de 2008 (a um trimestre da publicação do Informe PBF n.ำ157, que comunicou aos municípios a instituição do IDF), Barros, Carvalho e Mendonça lançaram o artigo "Sobre as utilidades do Cadastro Único", no qual os autores consideram que “em função do seu elevado grau de cobertura da população pobre do país, 
pela ampla variedade de informações sobre as suas condições de vida, e por contar com nome e endereço desta população" o Cadastro Único se destaca "entre as mais importantes fontes de informação sobre a população pobre" (BARROS; CARVALHO; MENDONÇA, 20o8, p. 4) e, em conta disso, o CadÚnico é tido como uma alternativa complementar aos censos demográficos na estimação do grau de carências das famílias pobres nos municípios, principalmente porque sua atualização se dá com maior frequência que o Censo. (BARROS; CARVALHO; MENDONÇA, 2008) Assim, a variedade de informações constantes do Cadastro Único permite a construção de "indicadores de condições de vida", tendo como parâmetro as seis dimensões formuladas na proposta original do IDF, com uma reformulação dos indicadores, reduzindo-os a um total de 41 itens (frente aos 48 da proposta inicial).

A partir desses indicadores, os autores desenvolveram um software específico que, com base nas informações do CadÚnico, seria utilizado para a avaliação das condições de vida das famílias pobres no Brasil, desde o nível familiar até o nacional. A operação desse aplicativo se dá por cruzamento de dados, os quais são apresentados em formulários detalhados e cujos resultados são acessados tanto em forma de planilha quanto graficamente, em modelo "radar".

Figura 3 - Índice de Desenvolvimento Familiar (IDF) - Interface do software

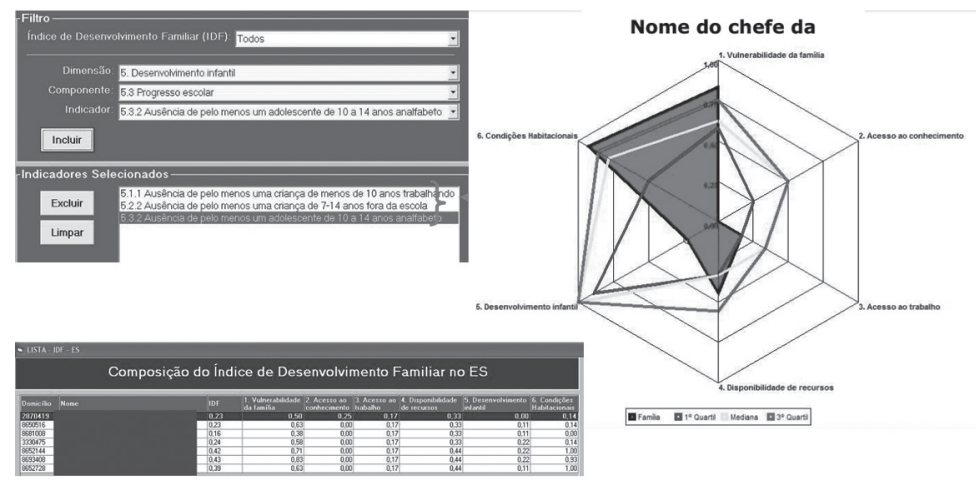

Fonte: Adaptada de Barros, Carvalho e Mendonça (2008).

É em referência a esse software que se publica o Informe $\mathrm{PBF} \mathrm{n}^{\circ}{ }^{157}$, de 30 de dezembro de 2008, comunicando a sua disponibilização aos municí- 
pios como ferramenta para a formulação de políticas públicas. Não se trata mais da divulgação dos resultados, como sugerido em 2006, mas do próprio instrumento para manipulação de acordo com o interesse dos gestores municipais.

Já em cinco de janeiro de 2009, o MDS publicou informações sobre os primeiros resultados obtidos a partir do IDF para o país, indicando que o conhecimento e o acesso ao trabalho representavam as principais carências das famílias inscritas no CadÚnico, com índices de o,36 e o,21 respectivamente, e, contrariamente, as melhores condições foram identificadas nos itens de desenvolvimento infantil $(0,93)$ e habitação $(0,73)$. O item relativo à disponibilidade de recursos alcançou o,42, e o de vulnerabilidade o,68. A média nacional ficou em o,55. (GARCIA, 2009).

À época da presente pesquisa (2010), o MDS dispunha de uma página virtual para a sua "Matriz de Informações Sociais", 77 onde oferecia diversos recursos para acessar informações variadas de suas bases de dados, cujos resultados poderiam ser apresentados de formas igualmente variadas. A visualização do mapa de seu "Atlas Social”, construído com base no IDF (Figura 4), por exemplo, permite que se tenha uma noção do quadro de distribuição da pobreza no Brasil no ano em que o IDF foi disponibilizado aos municípios (2008) e no ano seguinte (2009), segundo os critérios do Cadastro Único.

Figura 4 - Distribuição da pobreza no Brasil segundo o IDF por município
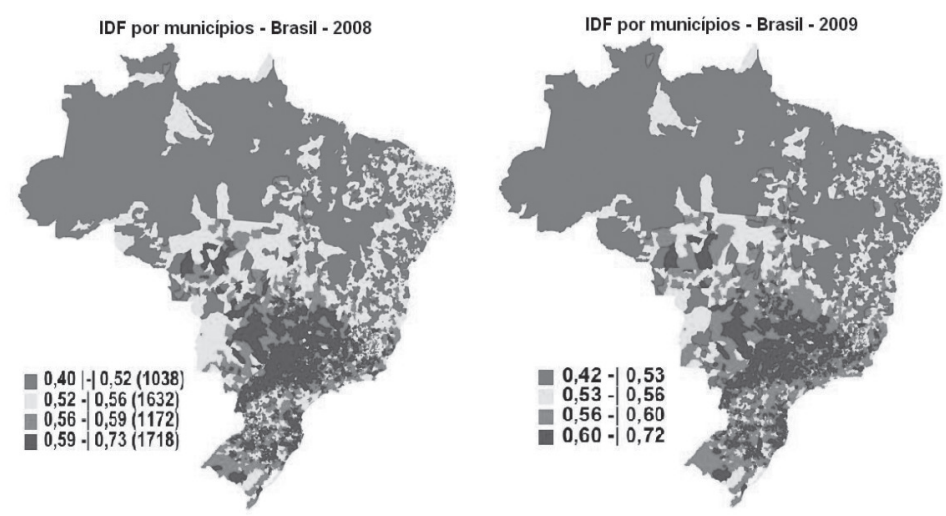

Fonte: Matriz de Informação Social - Atlas Social (2010)

77 Através do link: <http://aplicacoes.mds.gov.br/sagi/mi2007/home/login.php> qualquer cidadão poderia cadastrar--se, com login e senha, e navegar através do sistema, selecionando os dados e gerando os mapas de seu interesse. 
Observe-se que as informações cobrem todo o território nacional, como um censo específico da pobreza brasileira. Essas informações poderiam ser obtidas para cada município e detalhadas por cada variável componente do IDF. Com essa nova ferramenta, pretendia-se que o Cadastro Único subsidiasse o Governo na formulação de políticas públicas específicas, como propunha a tese de criação do IDF. 